\title{
Hybrid Solid State Supercapacitors (HSSC's) for High Energy \& Power Density: An Overview
}

\author{
Satyajeet S. Patil, ${ }^{1}$ Tejasvinee S. Bhat, ${ }^{1,2}$ Aviraj M. Teli, ${ }^{1}$ Sonali A. Beknalkar, ${ }^{1}$ Sarika B. Dhavale,,${ }^{1}$ Minaj M. Faras, ${ }^{1}$ Milind
} M. Karanjkar ${ }^{3}$ and Pramod S. Patil ${ }^{1,2, *}$

\begin{abstract}
A hybrid supercapacitor (HSC) is a supercapacitor (SC) based on two different electrode materials. One electrode is based on battery type faradic reactions (also known as extrinsic pseudocapacitor), and the other is based on the electric double-layer capacitor (non-faradic, known as intrinsic pseudocapacitor). In HSC, generally negative electrode material includes carbonbased materials (such as activated carbon, carbon nanotubes (CNT's) and graphene), metal oxides (such as $\mathrm{V}_{2} \mathrm{O}_{5}$ and $\mathrm{MoO}_{3}$ ), and their composites, while positive electrode materials are $\mathrm{Ni}$, Co-based, mixed metal oxide, binary metal-based, layered double hydroxide (LDH) based materials etc. The synergy between high conductivity, specific surface area of negative electrode and architectures, heterostructures of positive electrodes is used to improve the overall electrochemical performances of the HSC's device. In this review, the basic charge storing mechanisms, a method for determination of capacitive and diffusion-controlled contribution, are explained. This review highlights the importance of hybrid solid-state supercapacitors (HSSC's) as energy storage devices. Finally, recent advancement in the HSSC fields is discussed and will guide future work in the HSSC field.
\end{abstract}

Keywords: Supercapacitors; Hybrid supercapacitors; Solid state devices; Asymmetric supercapacitors; Battery materials.

Received: 16 August 2020; Accepted: 15 September 2020.

Article type: Review article.

\section{Introduction}

In recent years, researchers are focusing on the development of the energy storage device to fulfill global energy demands. ${ }^{[1,2]}$ The increasing demand for efficient, durable, safe, sustainable energy sources have swelling interests in the development of innovative electrode materials for advanced energy storage devices like batteries and electrochemical capacitors. ${ }^{[3,4]}$ Among these energy storage devices, supercapacitors (SC's) have gain attention as next-generation energy storage device due to its high power density than batteries and dielectric capacitors. ${ }^{[5]}$ Electrode materials play a vital role in the progress of high-performance SC devices in terms of morphology, surface area, and porosity. ${ }^{[6-9]}$

Recently the research concentrated on pseudocapacitors

\footnotetext{
${ }^{I}$ Thin Film Materials Laboratory, Department of Physics, Shivaji University, Kolhapur 416 004, M.S., India

${ }^{2}$ School of Nanoscience and Technology, Shivaji University, Kolhapur 416004, M.S., India

${ }^{3}$ Department of Physics, Vivekanand College, Kolhapur 416003, M.S., India.

*E-mail: psp_phy@unishivaji.ac.in (P. S. Patil)
}

(PC's) because of their high energy density than electrochemical double-layer capacitors (EDLC's). ${ }^{[10,11]}$ Based on the energy storage mechanism, SC's are classified into two classes: EDLC ${ }^{[12-14]}$ and PC. ${ }^{[15,16]}$ EDLC's can store the charge in an electrostatical manner, which does not include the transfer of charge between electrode and the electrolytic ions. ${ }^{[17]}$ While PC's store charges via the faradic process, which involves the transfer of charges between electrode and electrolyte. ${ }^{[18]}$ EDLC's offer excellent cyclic stability and power performance while the PC's exhibit high energy density. ${ }^{[19]}$ EDLC electrode materials are basically carboneous materials like activated carbon (AC), ${ }^{[20]}$ carbon nanofibers, ${ }^{[21]}$ graphene, ${ }^{[22-24]}$ and carbon nanotubes (CNT's) ${ }^{[25]}$ On the other hand, metal oxides, ${ }^{[26-31]}$ and conducting polymers ${ }^{[32-34]}$ are pseudocapacitive materials due to their redox charge storage mechanism. In the case of the hybrid system, it provides an advantage of both, by combining the energy source of the battery-like electrode with a power source of the capacitor-like electrode in a single device. By selecting a suitable electrode material combination, it is possible to increase the working potential window, which in turn leads to an enhancement in both power and energy densities. ${ }^{[35,36]}$ 


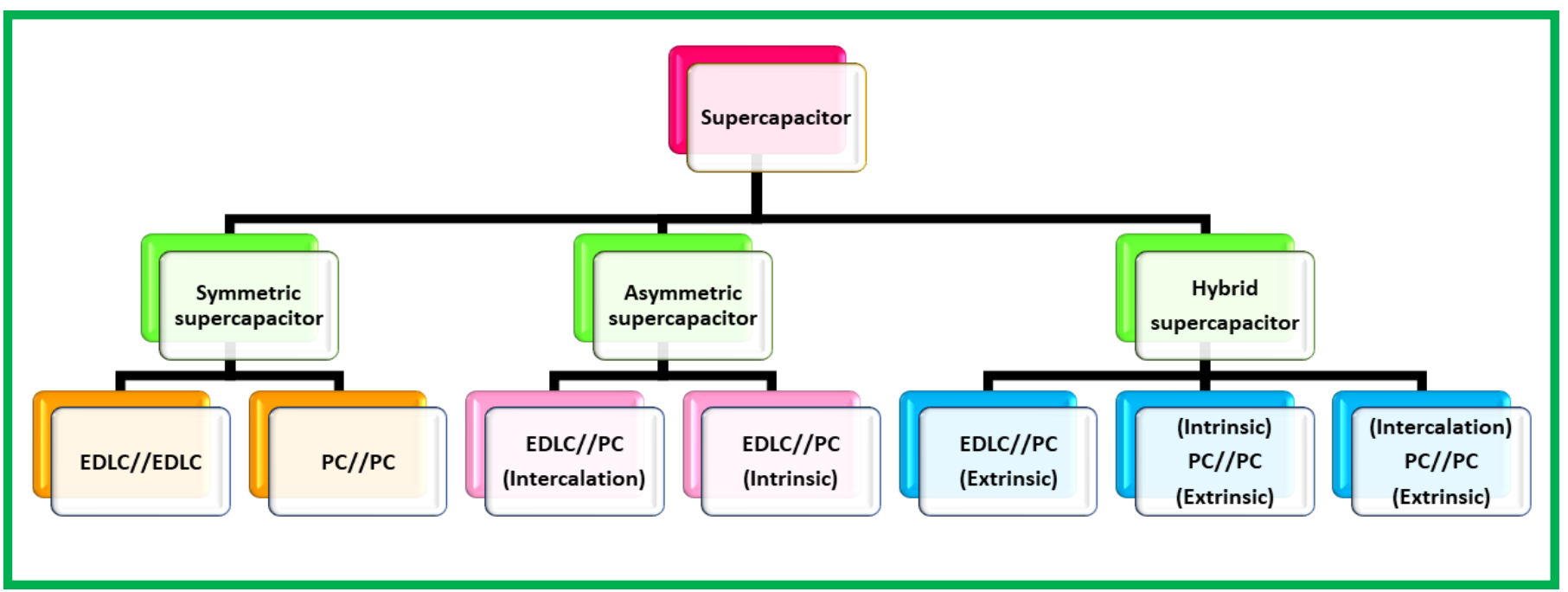

Fig. 1 Types of supercapacitors based on device configuration.

Besides this, the rapid advancement of portable electronic gadgets pull in to explore the novel integrated energy storage devices with lightweight, flexible, and even rollup characteristics. ${ }^{[37,38]}$ Inspired by these necessities, wideranging research focused on developing hybrid supercapacitors (HSC's) as well as asymmetric supercapacitors (ASC's). Several configurations are studied by the researcher in the past few years for both electrodes in several electrolytes. ${ }^{[39,40]}$ Recently, research is focused on developing various types of SC devices. ${ }^{[41]}$ These $\mathrm{SC}$ devices distinguished according to different mechanism-based electrode configurations such as symmetric, ${ }^{[42]}$ asymmetric, ${ }^{[43]}$ and hybrid ${ }^{[40]}$ devices as shown in Fig. 1.

Brousse et al. ${ }^{[44]}$ reported a difference between PC's and battery materials. Pseudocapacitance is provided by electrode materials exhibiting a linear relationship between the charges stored and changing potential. Materials such as $\mathrm{RuO}_{2}{ }^{[4]}$ and $\mathrm{MnO}_{2},{ }^{[46]}$ show curves in cyclic voltammetry $(\mathrm{CV})$ and

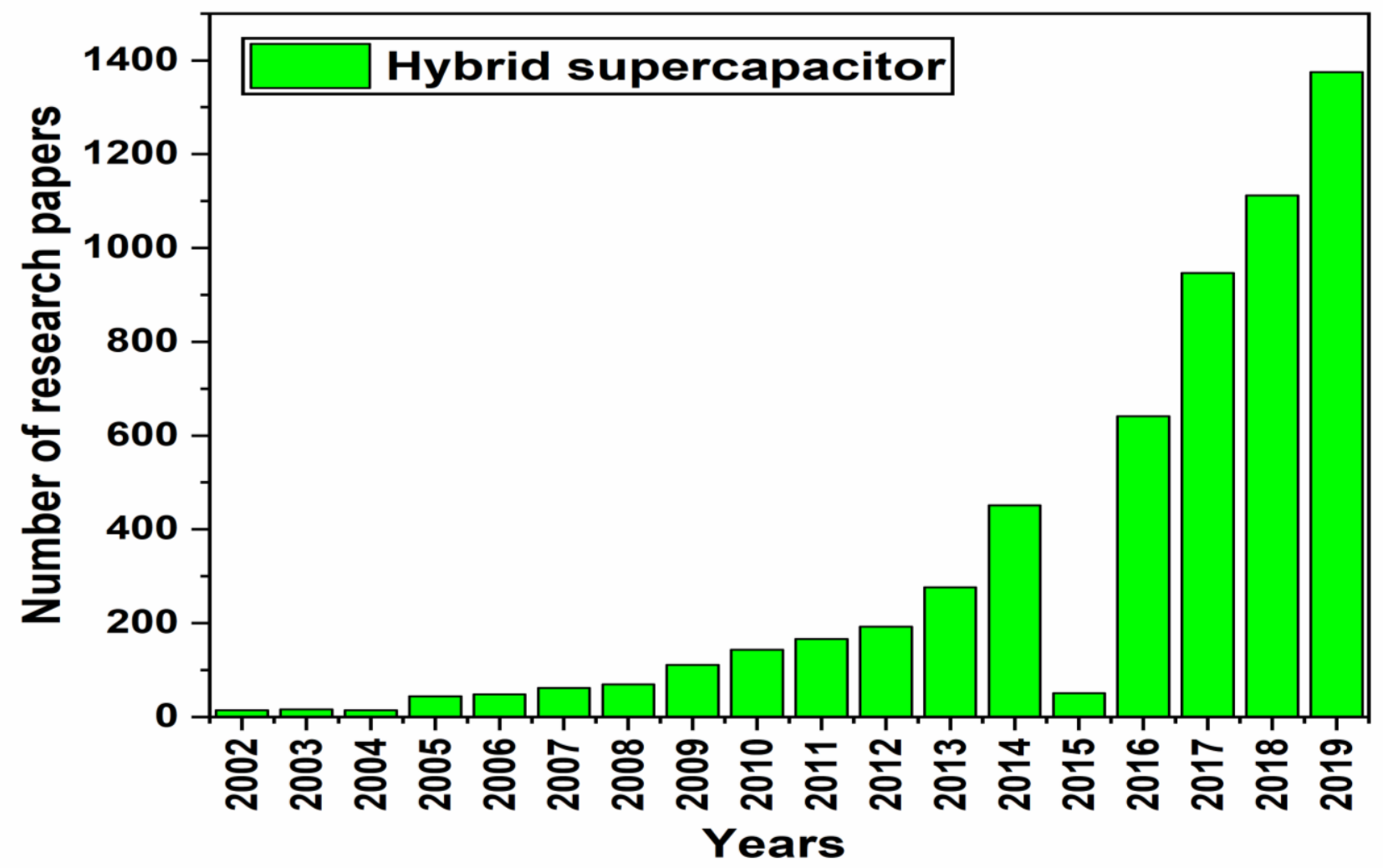

Fig. 2 Reported research papers from the year 2000 onwards with search keyword 'Hybrid Supercapacitor' (www.scopus.com). 


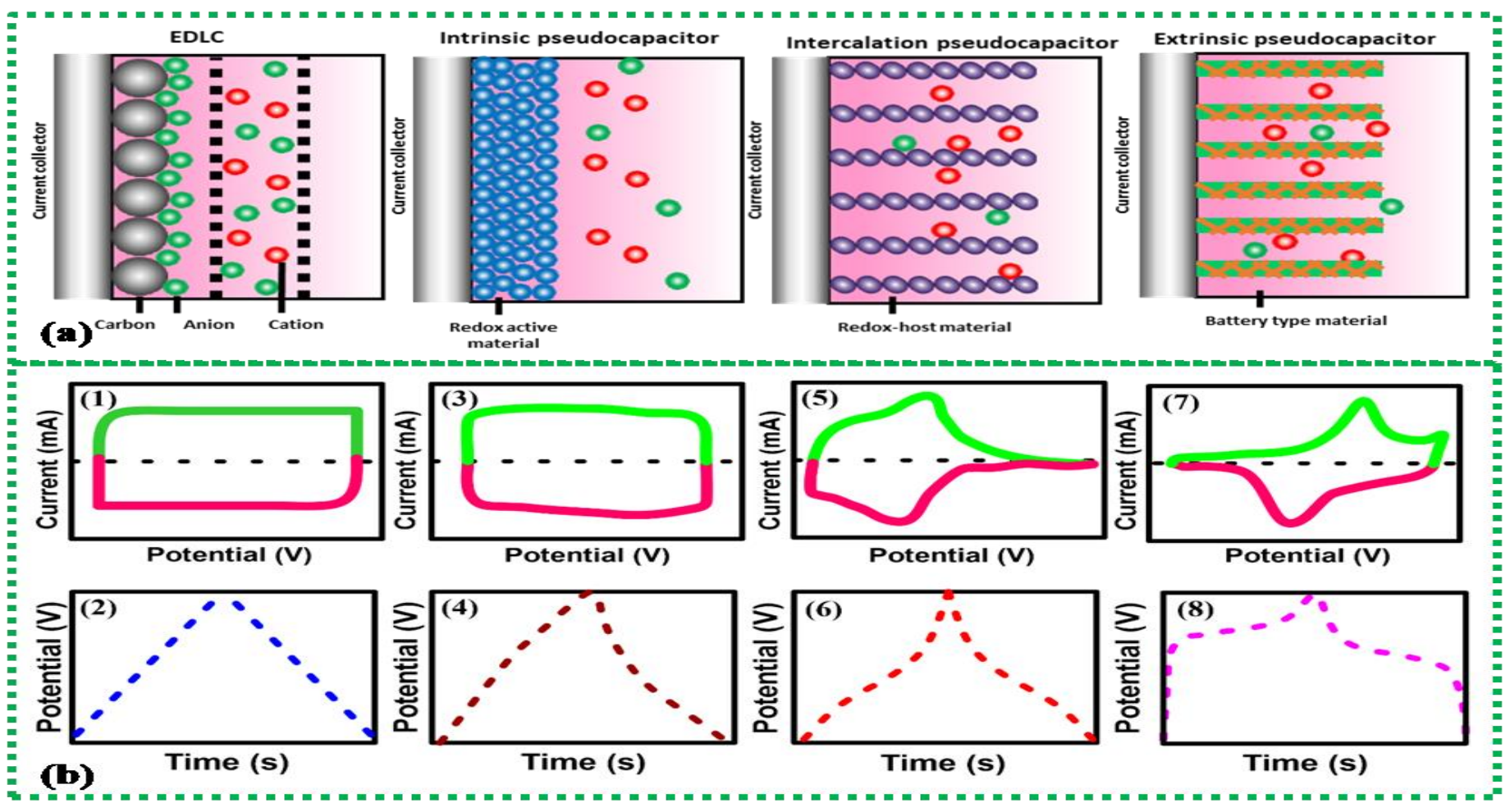

Fig. 3 (a) The schematic representation of the energy storage mechanisms in supercapacitors. (b) Electrochemical signatures (illustrative shapes of cyclic voltammograms and corresponding galvanostatic discharge curves): 1-2) electrical double layer capacitance, 3-4) intrinsic pseudocapacitor, 5-6) intercalation pseudocapacitor, and 7-8) extrinsic pseudocapacitor.

galvanic charge-discharge (GCD) analysis, similar to EDLC can be included in pseudocapacitive materials. The batterytype electrodes like $\mathrm{LiMn}_{2} \mathrm{O}_{4},{ }^{[47]} \mathrm{PbO}_{2},{ }^{[48]}$ etc. should not be considered as pseudocapacitive materials. ${ }^{[49]}$ According to Brousse, ${ }^{[50]}$ a device with a pseudocapacitive (intrinsic PC or intercalation PC) electrode along with the EDLC electrode is termed as "ASC". Also, the terminology "HSC" should be used for a device having one battery type (extrinsic PC) electrode and EDLC as another electrode as shown in Fig. 1. SC's have low energy density while batteries have low power density. However, in the case of non-aqueous lithium ion batteries and $\mathrm{Pb}$-acid batteries, safety issues cannot be ignored due to their deadly and flammable organic electrolytes. Hence, HSC tackles all the difficulties, which have been faced in SC's and batteries by the advantages of a combination of the high energy density of batteries along with the high power density of SC. ${ }^{[51,52]}$ As shown in Fig. 2, from the year 2000 onwards, a large number of researchers are attracted towards HSC. In comparison with the SC's using liquid electrolyte, all solidstate SC's have certain benefits such as enhanced flexibility, safety, and lightweightness, which are basic needs of flexible and portable energy storage devices. ${ }^{[53,54]}$ Thus, hybrid solidstate supercapacitors (HSSC) can be prominent devices to utilize for commercial applications. ${ }^{[55,56]}$
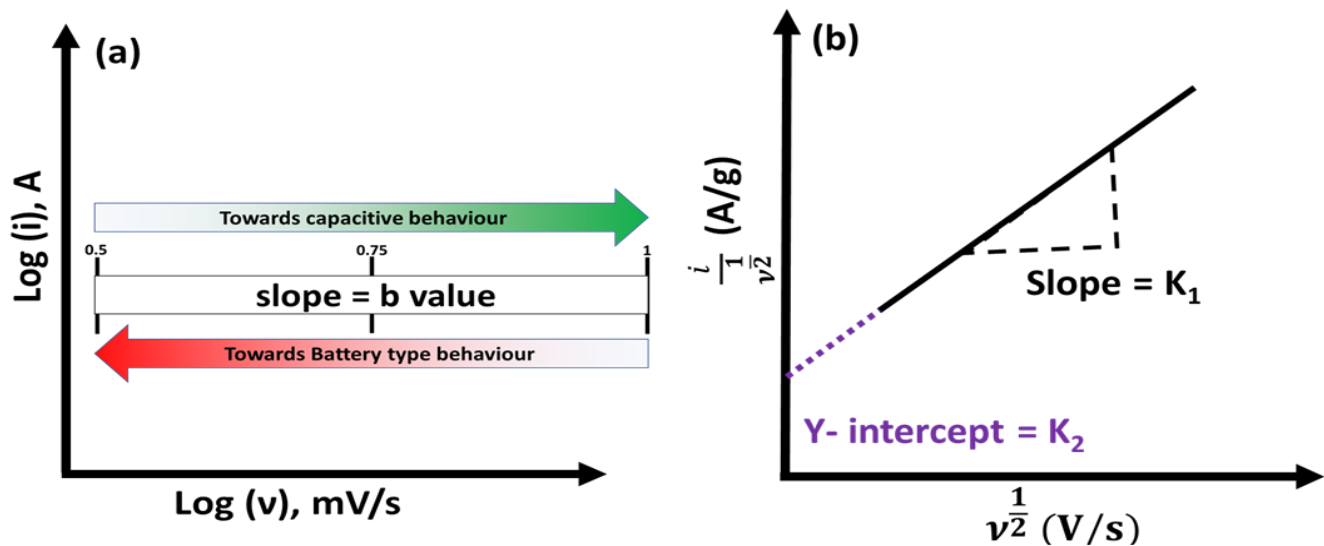

Fig. 4 (a) The plot of $\log (i)$ versus $\log (v)$ for calculation of b value. (b) Plot for calculation of $K_{1}$ and $K_{2}$ parameters. 


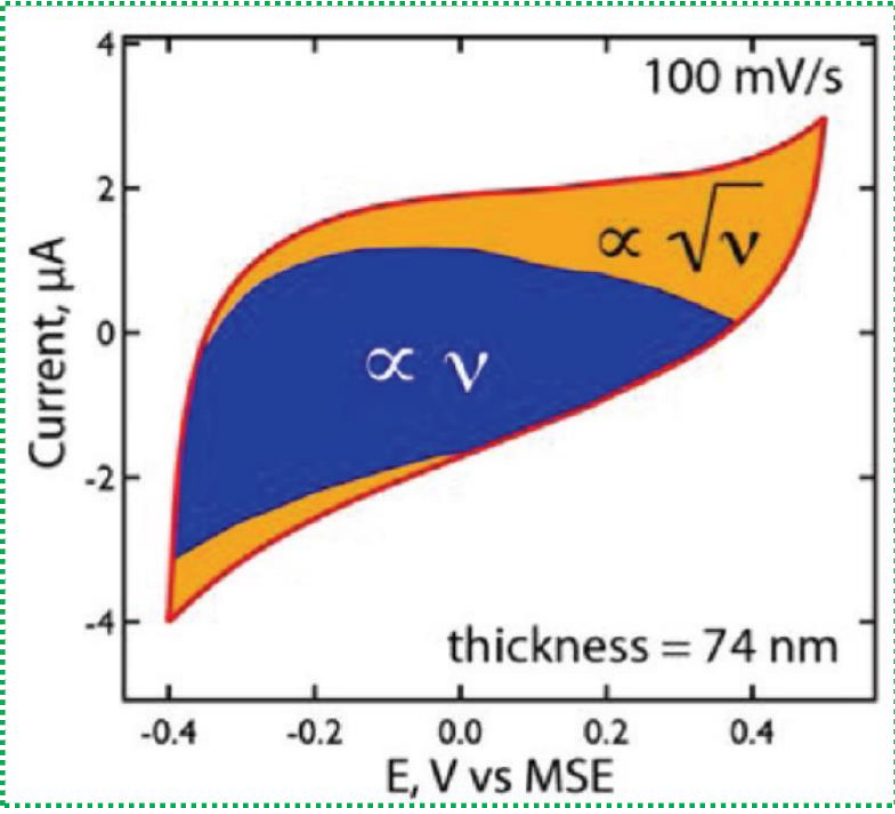

Fig. $5 \mathrm{CV}$ of $\mathrm{Au} / \mathrm{MnO}_{2}$ core-shell nanowires differentiated into capacitive and diffusion contributions at $100 \mathrm{mV} / \mathrm{s}$, reproduced with permission from [84].

\section{Charge storage mechanisms}

In this section, we have discussed the basic mechanisms to understand the charge storing principle in SC's. All the mechanism illustrations and their electrochemical profiles are shown schematically in Fig. 3 (a \& b), respectively, will help in understanding EDLC as well as PC energy storage mechanisms.

\subsection{Electric Double Layer Capacitance (EDLC)}

An electric double-layer capacitor is the traditional and thoroughly studied form of SC where the charge storage arises due to the physio-sorption of electrolytic ions on the electrode surface. ${ }^{[57]}$ As the charge storage is physical in nature, the surface area plays an important role in EDLC. The capacitance of EDLC firmly resides upon the surface properties of electrode material like specific surface area, pore size, and pore-size distribution. ${ }^{[58]}$ The Helmholtz model is the simplest model used to explain this mechanism as double-layer capacitance using Equation (1) for the parallel plate capacitor as:

$$
\mathrm{c}=\frac{\varepsilon \mathrm{A}}{\mathrm{d}}
$$

where $\mathrm{C}$ is the capacitance of EDLC, $\varepsilon$ is the permittivity of the dielectric medium, $\mathrm{A}$ is the surface area of the electrode, and $\mathrm{d}$ is the distance between the electrode and electrolytic ions. The carbon-based materials like AC, ${ }^{[59]} \mathrm{CNT}$ 's, ${ }^{[60]}$ carbon aerogels, ${ }^{[61]}$ graphene, ${ }^{[62]}$ carbide-derived carbons, ${ }^{[63]}$ and carbon nanofibers ${ }^{[64]}$ possess this type of charge storage mechanism. The electrochemical features of EDLC based materials are shown in Fig. 3 (b). From this, we can observe that the CV curves are rectangular in shape, while the GCD profiles show a linear charge-discharge pattern. As the charge storage in EDLC is electrostatic in nature, so they respond immediately to potential changes. Therefore, they have high power density, but low energy density because of the absence of faradic reaction, i.e., physical adsorption of electrolytic ions resists its energy density, which sets up a hindrance for its practical utility. ${ }^{[65]}$

\subsection{Pseudocapacitors (PC's)}

PC's described by Conway are for the materials, which possess electrochemical characteristics similar to EDLC, but the charge storage mechanism is quite different from those of conventional EDLC's. ${ }^{[66]}$ The PC's store the charges through faradic redox reactions, which are highly reversible and occur at the surface and sub-surface region. Based on the charge storage mechanism, the PC's are again classified into three sub-categories: ${ }^{[67]}$

1) Surface- redox reactions;

2) Intercalation-type reactions;

3) Battery type faradic reactions.

\subsubsection{Surface redox reactions/Intrinsic $\mathbf{P C}$}

The intrinsic pseudocapacitive materials mainly store charges by redox reactions occurring at the surface or sub-surface regions. ${ }^{[68]}$ From Fig. 3 (b), the $\mathrm{CV}$ and GCD profiles of intrisnsic $\mathrm{PC}$, we can see that they have similar characteristic features to that of EDLC. However, due to the faradic charge storage mechanism, a 2-fold increase in capacitance can be observed for intrinsic pseudocapacitive materials over the conventional EDLC's. ${ }^{[69]}$ The materials like ruthenium oxide $\left(\mathrm{RuO}_{2}\right)$ and manganese oxide $\left(\mathrm{MnO}_{2}\right)$ show intrinsic pseudocapacitive behavior. ${ }^{[70,71]}$ These materials have multiple valence states, through which fast and reversible redox reactions can be possible, making them better than EDLC's in terms of energy density.

\subsubsection{Intercalation-type reactions/intercalation PC}

In the $21^{\text {st }}$ century, Dunn and Simon introduced intercalation charge storage mechanism. ${ }^{[72,73]}$ Layered materials such as $\mathrm{Nb}_{2} \mathrm{O}_{5},{ }^{[74]} \mathrm{TiO}_{2},{ }^{[75]}$ and $\mathrm{MoO}_{3}{ }^{[15]}$ undergo faradic charge transfer due to the intercalation of electrolyte ions into the layers without any change in phase. Due to no phase transformation during intercalation, this mechanism is independent of rate, exhibiting redox peaks in the $\mathrm{CV} . \mathrm{Nb}_{2} \mathrm{O}_{5}$ is a representative example of an intercalation $\mathrm{PC}$. The reaction mechanism of lithium ions into $\mathrm{Nb}_{2} \mathrm{O}_{5}$ is as follows,

$$
\mathrm{Nb}_{2} \mathrm{O}_{5}+\mathrm{xLi}^{+}+\mathrm{xe}^{-} \leftrightarrow \mathrm{Li}_{\mathrm{x}} \mathrm{Nb}_{2} \mathrm{O}_{5}
$$

The materials with intercalation pseudocapacitors are promising for high rate charge storage devices.

\subsubsection{Battery type faradic reactions/extrinsic PC}

With the help of cutting edge technology and advancement in instrumentation, this mechanism was introduced by Dunn and others. ${ }^{[76]}$ The name includes the word battery due to the involvement of nanostructured battery materials in SC applications. Examples of extrinsic PC include $\mathrm{LiCoO}_{2},{ }^{[77]}$ $\mathrm{MoO}_{3-\mathrm{x}}{ }^{\left[{ }^{[78]}\right.} \mathrm{LaMnO}_{3-\mathrm{x}}{ }^{[79]}$ etc. These materials show well- 

defined redox peaks in CV and plateau in GCD as represented
in Fig. 3 (b), like a battery. Nanostructured battery materials, show pseudocapacitive electrochemical features and hence must be termed as extrinsic pseudocapacitors. Choi et al. ${ }^{[76]}$ showed that how the GCD electrochemical profile of lithium cobalt oxide changed by variation of size from bulk to nano.

For HSC devices, specific capacity can be evaluated using the following expressions from $\mathrm{CV}$, ${ }^{180]}$

$$
\text { specific capacity }\left(\frac{\mathrm{Ah}}{\mathrm{g}}\right)=\frac{\int i(\mathrm{~V}) \times \mathrm{dV}(\mathrm{AV})}{2 \times \mathrm{m}(\mathrm{g}) \times v\left(\frac{\mathrm{V}}{\mathrm{s}}\right) \times 3600}
$$

and $\mathrm{m}$ is the mass loading of active material. From GCD,

$$
\text { specific capacity }\left(\frac{\mathrm{Ah}}{\mathrm{g}}\right)=\frac{\int i(\mathrm{~A}) \times \mathrm{d} t(\mathrm{~s})}{\mathrm{m}(\mathrm{g}) \times 3600}
$$

where $i$ is applied current density, $t$ is discharge time (s), $\mathrm{m}$ is the mass loading of the active material $(\mathrm{g})$. The energy efficiency can be calculated as follows: ${ }^{[81]}$

$$
\text { energy efficiency }=\frac{E_{\text {discharge }} \times 100}{E_{\text {charge }}}
$$

where $i$ is current over voltage window $(\mathrm{V}), v$ is scan rate $(\mathrm{V} / \mathrm{s})$,
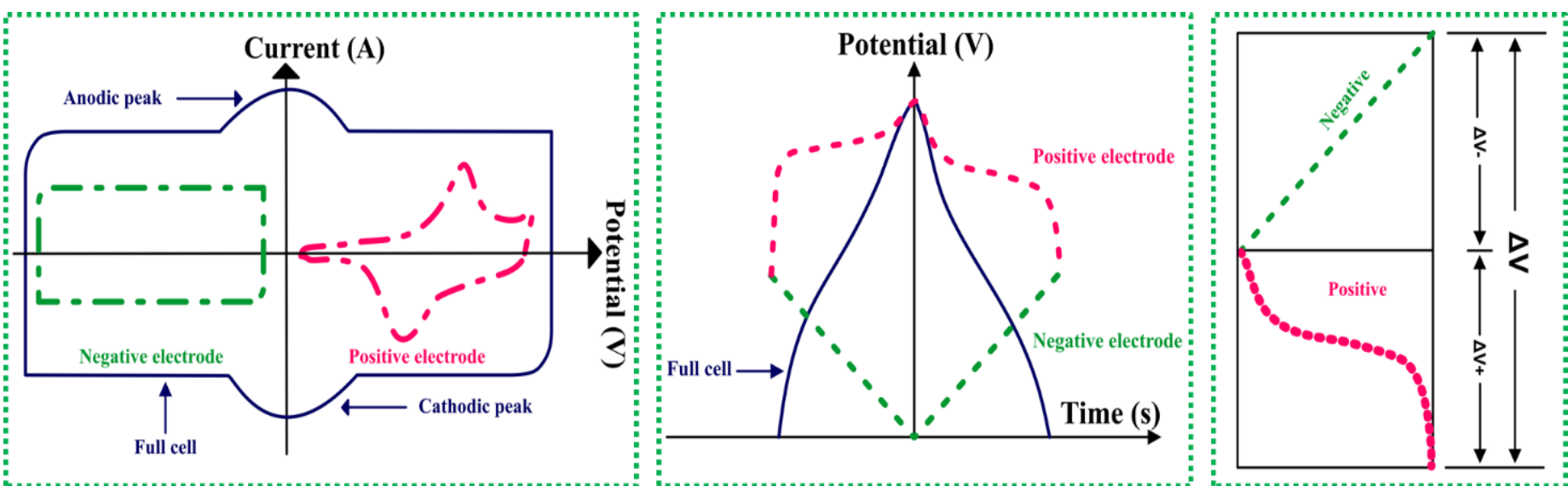

Fig. 6 Electrochemical signature of hybrid supercapacitor electrodes.

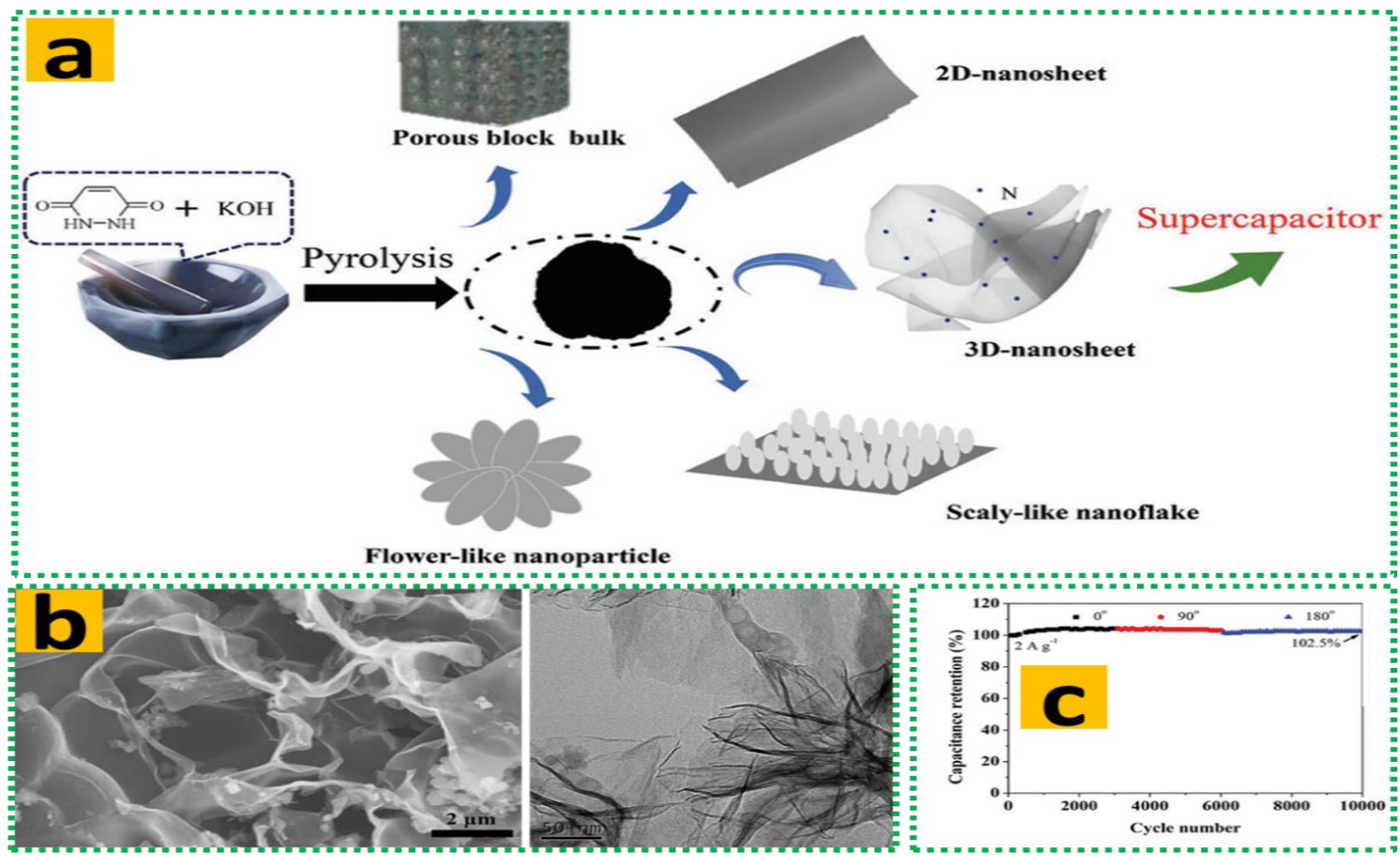

Fig. 7 (a) Synthesis strategy scheme for N-doped porous carbons. (b) SEM and TEM images of nanosheet structured N-doped porous carbons. (c) Capacitance retention study of the device at $2 \mathrm{~A} / \mathrm{g}$ over 10,000 cycles, reproduced with permission from [87]. 


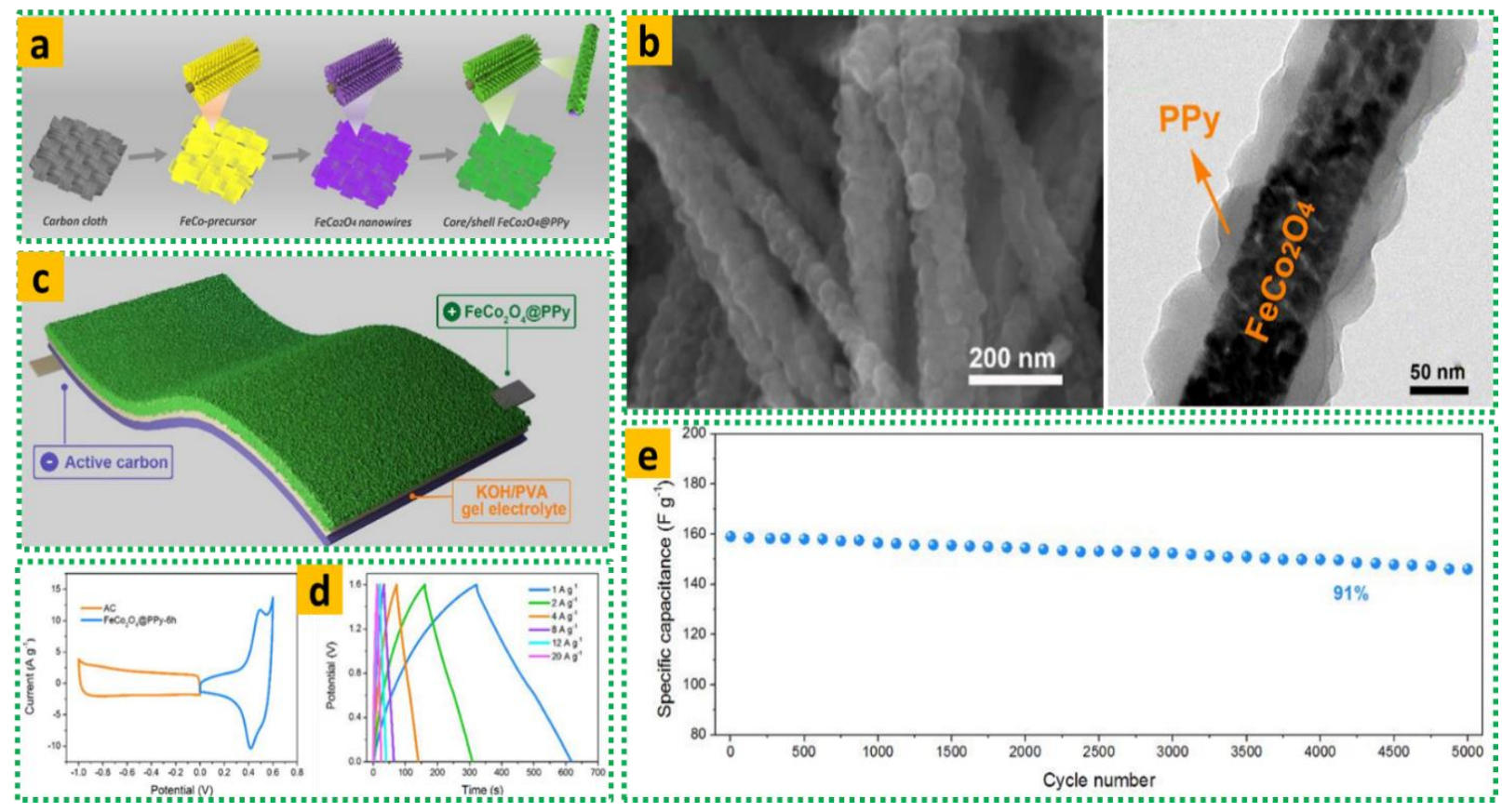

Fig. 8 (a) Synthesis scheme illustration of $\mathrm{FeCo}_{2} \mathrm{O}_{4} @$ PPy. (b) FESEM and TEM images of FeCo $\mathrm{O}_{4} @ \mathrm{PPy}$. (c) Schematic representation of the $\mathrm{ASC}$ based on $\mathrm{FeCo}_{2} \mathrm{O}_{4} @ \mathrm{PPy}$ and $\mathrm{AC}$ (d) Comparative CV curves of the FeCo $\mathrm{O}_{4} @ \mathrm{PPy}$ and AC electrodes at $5 \mathrm{mV} / \mathrm{s}$. GCD curves of ASC device at various current densities. (e) Cyclic stability of ASC device at a current density of $8 \mathrm{~A} / \mathrm{g}$ for 5,000 cycles, reproduced with permission from [88].

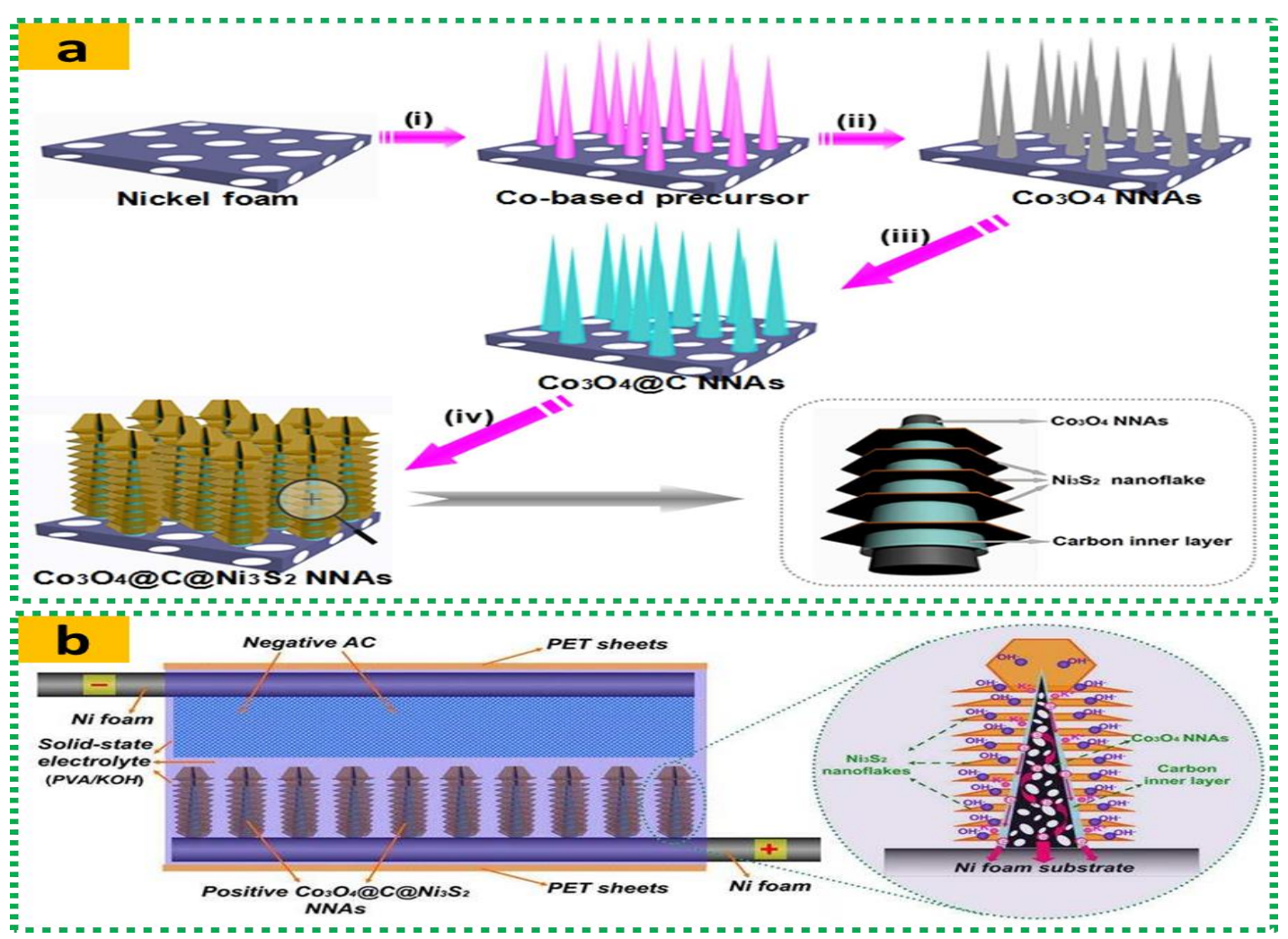

Fig. 9 (a) Schematic route for $\mathrm{Co}_{3} \mathrm{O}_{4} @ \mathrm{C} @ \mathrm{Ni}_{3} \mathrm{~S}_{2}$ sandwich-structured nanoneedle arrays on Ni foam: (i) hydrothermal synthesis; (ii) annealing; (iii) carbon painting; (iv) the second hydrothermal synthesis. (b) Schematic illustration of the hybrid solid-state supercapacitor device, reproduced with permission [93]. 


\section{Method for determination of capacitive and diffusion controlled faradic contribution}

To understand the electrochemical features of the SC electrodes, various tools are used, such as CV, GCD, and electrochemical impedance spectroscopy (EIS) analysis. Among them, CV measurement is an essential tool to understand the electrochemical features of the electrodes. Simple CV measurements at different scan rates can be useful for the distinction of faradaic and capacitive contribution. At a specific potential, the power-law can be given as: ${ }^{[82]}$

$$
i=k v^{b}
$$

where both $k$ and $b$ are variable parameters, and $v$ is the scan rate. The value of $b$ in the above equation is calculated from the slope of the plot of $\log (i)$ versus $\log (v)$. Its value represents the dominant charge storage process, i.e., charge diffusion faradaic or capacitive, as shown in Fig. 4 (a). It also provides a kinetic indication in the form of charge storage mechanisms at different potentials and sweep rates.

For the ideal diffusion-limited faradaic process, $b=0.5$ $\left(i \propto \cup^{\frac{1}{2}}\right)$, if $b=1$, then most of the charge contributions are from high rate surface-controlled redox reactions and the adsorption/desorption of the electrolyte ions $(i \propto v))^{[82]}$ According to the following Randle-Sevcik Equation: ${ }^{[83]}$

$$
\mathrm{i}=\chi(\mathrm{bt}) \mathrm{nFAC}\left(\frac{\pi \alpha \mathrm{nFDv}}{\mathrm{RT}}\right)^{\frac{1}{2}}
$$

where $\mathrm{A}$ is the electrode area, $\mathrm{n}$ is the number of electrons participating in the electrochemical process, $\alpha$ is the transfer coefficient, $v$ is the scan rate, function $(b t)$ symbolizes the normalized current, $\mathrm{R}$ is the ideal gas constant, $\mathrm{F}$ is the Faraday constant, $\mathrm{C}$ is the surface concentration of the electrode material, D is the chemical diffusion coefficient, and $\mathrm{T}$ is the temperature.

To determine the quantitative contribution of both capacitive $\left(\mathrm{k}_{1} v\right)$ and diffusion $\left(\mathrm{k}_{2} \mathrm{~V}^{1 / 2}\right)$ charge storage behavior over total current determined by Equations (8\&9):

$$
\begin{aligned}
& \mathrm{i}=\mathrm{i}_{\text {cap }}+\mathrm{i}_{\text {diff }} \\
& \mathrm{i}=\mathrm{k}_{1} v+\mathrm{k}_{2} v^{\frac{1}{2}}
\end{aligned}
$$

Rearranging the above equation, we get,

$$
\frac{\mathrm{i}}{v^{\frac{1}{2}}}=k_{1} v^{\frac{1}{2}}+k_{2}
$$

As we know the general equation straight-line as,

$$
y=m x+C
$$

where the straight line is having slope $\mathrm{m}$ and the $\mathrm{y}$-intercept $\mathrm{C}$. Now, compare with the general equation of the straight line. To determine the value of $\mathrm{k}_{1}$, lets plot $\mathrm{i} / v^{\frac{1}{2}}$ versus $v^{\frac{1}{2}}$ as shown in Fig. 4 (b). The slope will give the value of $k_{1}$ and the $y$-axis intercept will give the value of $k_{2}$ parameters.

After getting the values of the quantities $\mathrm{k}_{1}$ and $\mathrm{k}_{2}$, then it is simple to separate the capacitive $\left(\mathrm{k}_{1} v\right)$ and the diffusion- controlled $\left(\mathrm{k}_{2} v^{\frac{1}{2}}\right)$ currents in the voltammograms as a function of varying potentials, as shown in Fig. 5.

\section{Hybrid solid state supercapacitors (HSSC's)}

HSC consists coupling of the capacitive electrode and battery type electrode. Recently, Chodanakar et al. ${ }^{[80]}$ clearly explained the difference between ASC and HSC. Fig. 6 shows the electrochemical signature of HSC. These HSC have promising features as improved specific capacity, energy density, and power density. However, they still need to be excelled, as compared to present SC devices. In this section, recent top research articles in the HSSC field are discussed. For positive electrode, metal, binary metal, mixed metal, battery type (in nanostructure), layered double hydroxide (LDH)-based electrodes are generally used. However, for the negative electrode, traditional carbon-based electrodes are used. The main aim of such development was to widen the potential window, increase in energy and power density with improved cyclic stability. For HSC, specific capacity and energy efficiency should be reported along with specific capacitance and coulombic efficiency using Equations (3), (4), and (5). ${ }^{[85]}$ However, to avoid the misperception of readers, here, we have discussed the metrics mentioned in corresponding papers.

Nickel and cobalt are mainly considered as battery materials due to strong redox behavior, but in the nanostructured form, they follow extrinsic pseudocapacitive mechanisms. Jio et al. ${ }^{[86]}$ studied the vital role of lattice distortions of materials in the case of metal-organic framework (MOF) derived $\mathrm{Ni} / \mathrm{NiO}$ as positive electrode and CNTs$\mathrm{COOH}$ as negative electrode to achieve $92 \%$ excellent stability over 10,000 cycles. Liu et al..$^{[87]}$ developed N-doped porous carbons (NPCs) with multiple shape-controlled and tunable morphologies by single-step pyrolysis/activation method. The synthesis method scheme, SEM, and TEM micrographs of nanosheet structured NPC are shown in Fig. 7 (a \& b). The maximum specific capacitance achieved by NPC as cathode and $\mathrm{NiCo}_{2} \mathrm{O}_{4}$ as anode is $120 \mathrm{~F} / \mathrm{g}$ at $1 \mathrm{~A} / \mathrm{g}$ with 42.7 $\mathrm{Wh} / \mathrm{kg}, 8,000 \mathrm{~W} / \mathrm{kg}$ maximum energy and power density respectively. The capacitance retention study is represented in Fig. 7 (c).

In another study, flexible ASC is fabricated with $\mathrm{FeCo}_{2} \mathrm{O}_{4} @$ polypyrrole $\left(\mathrm{FeCo}_{2} \mathrm{O}_{4} @\right.$ PPy) core/shell nanowires as anode and $\mathrm{AC}$ as cathode. Due to the obtained hierarchical nanostructure, the ASC device delivers an impressive energy density of $68.8 \mathrm{Wh} / \mathrm{kg}(800 \mathrm{~W} / \mathrm{kg})$ and a long cycle lifetime (91\% over 5000 cycles). ${ }^{[88]}$ For $\mathrm{FeCo}_{2} \mathrm{O}_{4} @$ PPy//AC: synthesis route schematic, FESEM and TEM micrographs, ASC device illustration, and electrochemical signature of the ASC device are shown in Fig. 8. 


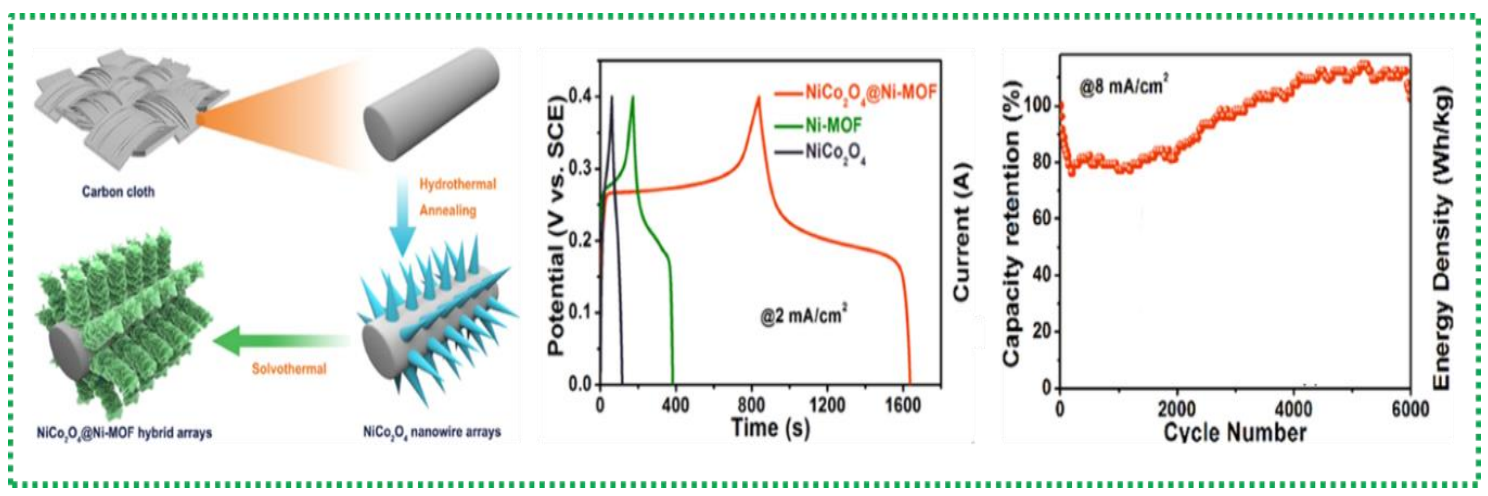

Fig. 10 Schematic illustration of the synthesis process for $\mathrm{NiCo}_{2} \mathrm{O}_{4} @ \mathrm{Ni}-\mathrm{MOF}$ electrode. GCD curve, capacity retention, and coulombic efficiency study of $\mathrm{NiCo}_{2} \mathrm{O}_{4} @ \mathrm{Ni}-\mathrm{MOF} / / \mathrm{AC}$ device, reproduced with permission from [97].

Further, HSC with $\mathrm{NiS} / \mathrm{Ni}_{3} \mathrm{~S}_{2}$ as a cathode and $\mathrm{AC}$ as an anode demonstrated an excellent specific capacity $(0.34$ $\mathrm{mAh} / \mathrm{cm}^{2}$ at $2 \mathrm{~mA} / \mathrm{cm}^{2}$ ) with enhanced cycling stability $(86.7 \%$ over 8,000 cycles)..$^{[89]}$ Moreover, Wang et al. ${ }^{[90]}$ developed 3D hierarchically porous electrode architecture with open pathways for the ASC device. In particular $\mathrm{Co}(\mathrm{OH})_{2} @$ carbonized wood $(\mathrm{CW}) / / \mathrm{CW}$ delivers maximum energy and power density of $0.69 \mathrm{mWh} / \mathrm{cm}^{2}, 15.447 \mathrm{~W} / \mathrm{cm}^{2}$ respectively and shows a sustained long lifespan as $85 \%$ of capacitance retention 10,000 cycles (at current density of 1 $\mathrm{A} / \mathrm{g})$. Wang et al. ${ }^{[91]}$ reported NiCoAl-layered double hydroxide/ $\mathrm{V}_{4} \mathrm{C}_{3} / / \mathrm{AC}$ configuration in the $\mathrm{KOH}$ electrolyte. The fabricated HSSC device shows excellent $71.7 \mathrm{Wh} / \mathrm{kg}$, $20,000 \mathrm{~W} / \mathrm{kg}$ maximum energy and power density, respectively. Liu et al. ${ }^{[92]}$ synthesized $2 \mathrm{D}$ carbon nanosheets via a one-step precipitation polymerization strategy with a notable specific surface area up to $3,292.3 \mathrm{~m}^{2} / \mathrm{g}$. The ASC device $\mathrm{Ni}_{0.1} \mathrm{Co}_{0.8} \mathrm{Mn}_{0.1} / / \mathrm{PAN}$ (Polyacrylonitrile)-derived carbon exhibit enhanced specific capacitance of $147 \mathrm{~F} / \mathrm{g}$ at 1 $\mathrm{A} / \mathrm{g}$. Also, the device has a long-term cycle stability as $89.5 \%$ of capacitance even after 10,000 cycles.

Cobalt composite such as cobalt oxides, cobalt hydroxides, Co-based sulfides/selenides with stable structures and attractive features have been used as positive electrodes in HSSC's. For example, Kong et al. ${ }^{[93]}$ synthesized threedimensional ternary porous hybrid architecture for next generations hybrid devices. Its fabrication route with the ASC solid-state device schematic is shown in Fig. 9. Wei et al. ${ }^{[94]}$ synthesized graphite nanosheet-supported $\mathrm{CoMoS}_{4}$ (GN$\mathrm{CoMoS}_{4}$ ) via a simple hydrothermal route. ASC with a configuration of GN-CoMoS$S_{4} / / \mathrm{AC}$ deliverded a maximum energy density of $42.85 \mathrm{Wh} / \mathrm{kg}$ with $900 \mathrm{~W} / \mathrm{kg}$ power density. The fabricated ASC had an impressive cycling stability, as $93.2 \%$ capacity remained after 8,000 cycles.

Recently, the transition metal phosphates showed a great potential as a promising candidate for the SC's. Chodankar et al. ${ }^{[95]}$ reported $\mathrm{MnO}_{2} @ \mathrm{Ni}_{2} \mathrm{P}_{2} \mathrm{O}_{7} / / \mathrm{AC}$ HSSC devices, which exhibited $66 \mathrm{Wh} / \mathrm{kg}$, and $640 \mathrm{~W} / \mathrm{kg}$ specific energy and power density, respectively. The HSSC device also exhibits only $7 \%$ retention in capacity after 10,000 cycles. Shrestha et al. ${ }^{[6]}$ developed $\mathrm{MnCo}_{2} \mathrm{O}_{4} @ \mathrm{~N}-\mathrm{C} @ \mathrm{MnO}_{2}$ as positive and nitrogendoped graphene as negative electrode for assembling \%asymmetric solid-state devices. The device was fabricated using the KOH-PVA gel electrolyte. The device showed a specific capacity of $85.3 \mathrm{mAh} / \mathrm{g}$ at a current density of 4 $\mathrm{mA} / \mathrm{cm}^{2}$. Also, the device delivered enhanced maximum energy and power density of $68.2 \mathrm{Wh} / \mathrm{kg}$ and $11,200 \mathrm{~W} / \mathrm{kg}$. The device retained a capacity of $91.1 \%$ after 10,000 consecutive charge/discharge cycles. Li et al. ${ }^{[97]}$ fabricated $\mathrm{NiCo}_{2} \mathrm{O}_{4} @ \mathrm{Ni}-\mathrm{MOF}$ using a simple two-step process as represented in Fig. 10. The flexible HSSC device has a configuration of $\mathrm{NiCo}_{2} \mathrm{O}_{4} @ \mathrm{Ni}-\mathrm{MOF} / / \mathrm{AC}$. Due to heterostructure of the hybrid electrode, enhanced performance was observed, exhibiting no retention in capacity after 6,000 charge/discharge cycles as depicted in Fig. 10.

Moreover, Xia et al ${ }^{[98]}$ synthesized $\mathrm{NiCo}_{2} \mathrm{O}_{4} @ \mathrm{NiMn}-\mathrm{LDH}$ and assembled HSSC device with $\mathrm{NiCo}_{2} \mathrm{O}_{4} @ \mathrm{NiMn}-\mathrm{LDH}$ and $\mathrm{AC}$ as positive and negative electrodes. The device showed an improved energy density of $47 \mathrm{Wh} / \mathrm{kg}$ at a power density of $357 \mathrm{~W} / \mathrm{kg}$. Qu et al. ${ }^{[99]}$ investigated nickel-cobalt phosphide nanostructures for HSSC's. The HSSC device had a configuration of $\mathrm{NiCoP} / / \mathrm{AC}$. The hybrid device exhibited a specific capacitance of $136 \mathrm{~F} / \mathrm{g}$ at $1 \mathrm{~A} / \mathrm{g}$ with a wide potential window of $1.6 \mathrm{~V}$. The hybrid device delivered maximum energy and power density of $48.4 \mathrm{Wh} / \mathrm{kg}$ and $13,000 \mathrm{~W} / \mathrm{kg}$, respectively. Further, He et al. ${ }^{[100]}$ reported three-dimensional nickel-cobalt phosphide porous nanoplates for solid-state hybrid supercapacitors with enhanced performance. With NiCoP and AC electrodes, the HSSC device exhibits impressive maximum energy and power density of 30.2 $\mathrm{Wh} / \mathrm{kg}, 12,620 \mathrm{~W} / \mathrm{kg}$, respectively.

Recently, Yin et al. ${ }^{[101]}$ reported a three-dimensional coreshell structure of $\mathrm{NiCo}_{2} \mathrm{O}_{4} @$ hafnium carbide $\left(\mathrm{NiCo}_{2} \mathrm{O}_{4} @ \mathrm{HfC}\right)$ on the carbon cloth. The HSSC was assembled using $\mathrm{NiCo}_{2} \mathrm{O}_{4} @ \mathrm{HfC}$ as positive and $\mathrm{AC}$ as negative electrodes. The device exhibited an excellent energy density of $53 \mathrm{Wh} / \mathrm{kg}$. It retained $94.8 \%$ of specific capacitance over 5,000 cycles of charge/discharge. Along with the above-discussed literature, similar to Ni and Co based ${ }^{[102-105]}$ high- performance, HSSC's electrochemical profiles are summarised in Table 1. 
Table 1. Summary of recent progress in hybrid solid-state supercapacitor devices.

\begin{tabular}{|c|c|c|c|c|c|c|c|c|}
\hline $\begin{array}{c}\text { Positive } \\
\text { electrode }\end{array}$ & $\begin{array}{l}\text { Negative } \\
\text { electrode }\end{array}$ & Electrolyte & $\begin{array}{c}\text { Potential } \\
\text { window } \\
{[\mathrm{V}]} \\
\end{array}$ & $\begin{array}{c}\text { Specific } \\
\text { capacitance }\end{array}$ & $\begin{array}{c}\text { Max. } \\
\text { energy } \\
\text { density }\end{array}$ & $\begin{array}{l}\text { Max. power } \\
\text { density }\end{array}$ & $\begin{array}{c}\text { Cycling } \\
\text { stability }[\%]\end{array}$ & Ref. \\
\hline $\begin{array}{l}\text { MOF-derived } \\
\mathrm{Ni} / \mathrm{NiO}\end{array}$ & CNT's-COOH & KOH/PVA & 1.8 & $\begin{array}{c}136.4 \mathrm{~F} / \mathrm{g} \text { at } \\
2 \mathrm{~mA} / \mathrm{cm}^{2}\end{array}$ & $\begin{array}{c}61.3 \\
\mathrm{Wh} / \mathrm{kg}\end{array}$ & $900 \mathrm{~W} / \mathrm{kg}$ & $\begin{array}{c}92.8 \text { over } \\
10,000 \text { cycles }\end{array}$ & {$[86]$} \\
\hline $\mathrm{NiCo}_{2} \mathrm{O}_{4}$ & $\begin{array}{l}\mathrm{N} \text {-doped } \\
\text { porous } \\
\text { carbons } \\
\end{array}$ & $\begin{array}{c}\mathrm{KOH} / \mathrm{PVA}- \\
\mathrm{PEO}\end{array}$ & 1.6 & $\begin{array}{c}120 \mathrm{~F} / \mathrm{g} \text { at } \\
1 \mathrm{~A} / \mathrm{g}\end{array}$ & $\begin{array}{c}42.7 \\
\mathrm{Wh} / \mathrm{kg}\end{array}$ & $8,000 \mathrm{~W} / \mathrm{kg}$ & $\begin{array}{c}94 \text { over } \\
10,000 \text { cycles }\end{array}$ & {$[87]$} \\
\hline $\begin{array}{l}\mathrm{FeCo}_{2} \mathrm{O}_{4} @ \\
\text { polypyrrole }\end{array}$ & $\mathrm{AC}$ & KOH/PVA & 1.6 & $\begin{array}{c}194 \mathrm{~F} / \mathrm{g} \text { at } \\
1 \mathrm{~A} / \mathrm{g}\end{array}$ & $\begin{array}{c}68.8 \\
\mathrm{Wh} / \mathrm{kg}\end{array}$ & $15,500 \mathrm{~W} / \mathrm{kg}$ & $\begin{array}{c}91 \text { over } \\
5,000 \text { cycles }\end{array}$ & [88] \\
\hline $\mathrm{NiS} / \mathrm{Ni}_{3} \mathrm{~S}_{2}$ & $\mathrm{AC}$ & KOH/PVA & 1.7 & $\begin{array}{c}0.34 \mathrm{mAh} / \mathrm{cm}^{2} \\
\text { at } \\
2 \mathrm{~mA} / \mathrm{cm}^{2}\end{array}$ & $\begin{array}{c}0.289 \\
\mathrm{mWh} / \mathrm{c} \\
\mathrm{m}^{2}\end{array}$ & $\begin{array}{c}12.825 \\
\mathrm{~mW} / \mathrm{cm}^{2}\end{array}$ & $\begin{array}{c}86.7 \text { over } \\
8,000 \text { cycles }\end{array}$ & [89] \\
\hline $\begin{array}{c}\mathrm{Co}(\mathrm{OH})_{2} @ \text { car } \\
\text { bonized wood } \\
(\mathrm{CW})\end{array}$ & $\mathrm{CW}$ & KOH/PVA & 1.5 & $\begin{array}{c}14.19 \mathrm{~F} / \mathrm{cm}^{3} \text { at } \\
1 \mathrm{~mA} / \mathrm{cm}^{2}\end{array}$ & $\begin{array}{c}0.69 \\
\mathrm{mWh} / \mathrm{c} \\
\mathrm{m}^{2}\end{array}$ & $15.447 \mathrm{~W} / \mathrm{cm}^{2}$ & $\begin{array}{c}85 \text { over } \\
10,000 \text { cycles }\end{array}$ & {$[90]$} \\
\hline $\begin{array}{c}\mathrm{NiCoAl-} \\
\mathrm{LDH} / \mathrm{V}_{4} \mathrm{C}_{3}\end{array}$ & $\mathrm{AC}$ & $\mathrm{KOH}$ & 1.6 & $194 \mathrm{~F} / \mathrm{g}$ at $1 \mathrm{~A} / \mathrm{g}$ & $\begin{array}{c}71.7 \\
\mathrm{Wh} / \mathrm{kg}\end{array}$ & $20,000 \mathrm{~W} / \mathrm{kg}$ & $\begin{array}{c}98 \text { over } \\
10,000 \text { cycles }\end{array}$ & {$[91]$} \\
\hline$\underset{1}{\mathrm{Ni} 0.1 \mathrm{Co} .8 \mathrm{Mn} 0 .}$ & $\begin{array}{l}\text { PAN-derived } \\
\text { carbon }\end{array}$ & KOH/PVA & 1.6 & $147 \mathrm{~F} / \mathrm{g}$ at $1 \mathrm{~A} / \mathrm{g}$ & $\begin{array}{c}52.47 \\
\mathrm{Wh} / \mathrm{kg}\end{array}$ & $8,000 \mathrm{~W} / \mathrm{kg}$ & $\begin{array}{c}89.5 \text { over } \\
10,000 \text { cycles }\end{array}$ & {$[92]$} \\
\hline $\begin{array}{c}\mathrm{Co}_{3} \mathrm{O}_{4} @ \mathrm{C} @ \mathrm{~N} \\
\mathrm{i}_{3} \mathrm{~S}_{2}\end{array}$ & $\mathrm{AC}$ & KOH/PVA & 1.8 & - & $\begin{array}{c}1.52 \\
\mathrm{mWh} / \mathrm{c} \\
\mathrm{m}^{3}\end{array}$ & $60 \mathrm{~W} / \mathrm{cm}^{3}$ & $\begin{array}{c}91.43 \text { over } \\
10,000 \text { cycles }\end{array}$ & {$[93]$} \\
\hline $\begin{array}{c}\text { Graphite@Co } \\
\mathrm{MoS}_{4}\end{array}$ & $\mathrm{AC}$ & KOH/PVA & 1.8 & $\begin{array}{c}95.11 \mathrm{~F} / \mathrm{g} \text { at } \\
1 \mathrm{~A} / \mathrm{g}\end{array}$ & $\begin{array}{c}42.85 \\
\mathrm{Wh} / \mathrm{kg}\end{array}$ & $4,500 \mathrm{~W} / \mathrm{kg}$ & $\begin{array}{c}93.2 \text { over } \\
8,000 \text { cycles }\end{array}$ & [94] \\
\hline $\begin{array}{c}\mathrm{MnO}_{2} @ \mathrm{Ni}_{2} \mathrm{P}_{2} \\
\mathrm{O}_{7} \\
\end{array}$ & $\mathrm{AC}$ & $\mathrm{KOH} / \mathrm{PVA}$ & 1.6 & $\begin{array}{c}82 \mathrm{mAh} / \mathrm{g} \text { at } 1 \\
\mathrm{~A} / \mathrm{g}\end{array}$ & $\begin{array}{c}66 \\
\mathrm{Wh} / \mathrm{kg}\end{array}$ & $1,920 \mathrm{~W} / \mathrm{kg}$ & $\begin{array}{c}93 \text { over } \\
10,000 \text { cycles }\end{array}$ & {$[95]$} \\
\hline $\begin{array}{c}\mathrm{MnCo}_{2} \mathrm{O}_{4} @ \mathrm{~N} \\
-\mathrm{C} @ \mathrm{MnO}_{2}\end{array}$ & $\begin{array}{l}\text { N-doped } \\
\text { graphene } \\
\text { hydrogel }\end{array}$ & KOH/PVA & 1.6 & $\begin{array}{c}85.3 \mathrm{mAh} / \mathrm{g} \text { at } 4 \\
\mathrm{~mA} / \mathrm{cm}^{2}\end{array}$ & $\begin{array}{c}68.2 \\
\mathrm{Wh} / \mathrm{kg}\end{array}$ & $11,200 \mathrm{~W} / \mathrm{kg}$ & $\begin{array}{c}91.1 \text { over } \\
10,000 \text { cycles }\end{array}$ & {$[96]$} \\
\hline $\begin{array}{c}\mathrm{NiCo}_{2} \mathrm{O}_{4} @ \mathrm{Ni}- \\
\mathrm{MOF}\end{array}$ & $\mathrm{AC}$ & KOH/PVA & 1.6 & $\begin{array}{c}41.5 \mathrm{mAh} / \mathrm{g} \text { at } 2 \\
\mathrm{~mA} / \mathrm{cm}^{2}\end{array}$ & $\begin{array}{c}32.6 \\
\mathrm{Wh} / \mathrm{kg} \\
\end{array}$ & $3,368.2 \mathrm{~W} / \mathrm{kg}$ & $\begin{array}{c}100 \text { over } \\
6,000 \text { cycles } \\
\end{array}$ & [97] \\
\hline $\begin{array}{c}\mathrm{NiCo}_{2} \mathrm{O}_{4} @ \mathrm{Ni} \\
\mathrm{Mn}-\mathrm{LDH}\end{array}$ & $\mathrm{AC}$ & KOH/PVA & 1.6 & $\begin{array}{c}\sim 38 \mathrm{mAh} / \mathrm{g} \text { at at } \\
2 \mathrm{~mA} / \mathrm{cm}^{2}\end{array}$ & $\begin{array}{c}47 \\
\mathrm{Wh} / \mathrm{kg}\end{array}$ & $357 \mathrm{~W} / \mathrm{kg}$ & $\begin{array}{c}95.6 \text { over } \\
5,000 \text { cycles }\end{array}$ & {$[98]$} \\
\hline $\mathrm{NiCoP}$ & $\mathrm{AC}$ & KOH/PVA & 1.6 & $136 \mathrm{~F} / \mathrm{g}$ at $1 \mathrm{~A} / \mathrm{g}$ & $\begin{array}{c}48.4 \\
\mathrm{Wh} / \mathrm{kg} \\
\end{array}$ & $13,000 \mathrm{~W} / \mathrm{kg}$ & $\begin{array}{c}88.8 \text { after } \\
8,000 \text { cycles }\end{array}$ & [99] \\
\hline $\mathrm{NiCoP}$ & $\mathrm{AC}$ & $\mathrm{KOH} / \mathrm{PVA}$ & 1.5 & $145 \mathrm{C} / \mathrm{g}$ at $1 \mathrm{~A} / \mathrm{g}$ & $\begin{array}{c}30.2 \\
\mathrm{Wh} / \mathrm{kg}\end{array}$ & $12,620 \mathrm{~W} \mathrm{~kg}$ & $\begin{array}{c}126 \text { after } \\
10,000 \text { cycles }\end{array}$ & [100] \\
\hline $\begin{array}{c}\mathrm{NiCo}_{2} \mathrm{O}_{4} @ \mathrm{Hf} \\
\mathrm{C} \\
\end{array}$ & $\mathrm{AC}$ & KOH/PVA & 1.6 & $149 \mathrm{~F} / \mathrm{g}$ at $1 \mathrm{~A} / \mathrm{g}$ & $\begin{array}{c}53 \\
\mathrm{Wh} / \mathrm{kg} \\
\end{array}$ & $2,400 \mathrm{~W} / \mathrm{kg}$ & $\begin{array}{c}94.8 \text { over } \\
5,000 \text { cycles }\end{array}$ & [101] \\
\hline $\mathrm{MnNiDH}$ & $\mathrm{AC}$ & KOH/PVA & 1.6 & - & $\begin{array}{c}30.63 \\
\mathrm{Wh} / \mathrm{kg} \\
\end{array}$ & $21,000 \mathrm{~W} / \mathrm{kg}$ & $\begin{array}{c}85.77 \text { over } \\
10,000 \text { cycles }\end{array}$ & [102] \\
\hline $\mathrm{NiCoP} / \mathrm{CNT}$ & CNT@N-C & - & 1.5 & $\begin{array}{c}123.3 \mathrm{mAh} / \mathrm{g} \text { at } \\
\text { current density } \\
1 \mathrm{~mA} / \mathrm{g}\end{array}$ & $\begin{array}{c}138.7 \\
\mathrm{Wh} / \mathrm{kg}\end{array}$ & $6,250 \mathrm{~W} / \mathrm{kg}$ & $\begin{array}{c}85 \text { over } 5,000 \\
\text { cycles }\end{array}$ & [103] \\
\hline $\mathrm{NiCo}-\mathrm{OH}$ & $\mathrm{AC}$ & KOH/PVA & 1.5 & $\begin{array}{c}167.8 \mathrm{C} / \mathrm{g} \text { at } 1 \\
\mathrm{~A} / \mathrm{g}\end{array}$ & $\begin{array}{c}27.9 \\
\mathrm{Wh} / \mathrm{kg}\end{array}$ & $\begin{array}{c}13,812.9 \\
\mathrm{~W} / \mathrm{kg}\end{array}$ & $\begin{array}{c}126 \text { over } \\
10,000 \text { cycles }\end{array}$ & [104] \\
\hline $\begin{array}{c}\mathrm{Ni}_{\mathrm{x}} \mathrm{Co}_{\mathrm{y}} \mathrm{MoO}_{4} \\
@ \mathrm{MoS}_{2} / \mathrm{CoS} / \\
\mathrm{NiS} \\
\end{array}$ & $\mathrm{AC}$ & - & 1.5 & $173 \mathrm{~F} / \mathrm{g}$ at $1 \mathrm{~A} / \mathrm{g}$ & $\begin{array}{c}60.4 \\
\mathrm{Wh} / \mathrm{kg}\end{array}$ & $15,500 \mathrm{~W} / \mathrm{kg}$ & $\begin{array}{c}94.4 \text { over } \\
5,000 \text { cycles }\end{array}$ & [105] \\
\hline
\end{tabular}

\section{Concluding remarks and future perspectives}

Flexible and efficient energy storage systems are needed in our daily life, and make our life easy and productive. As discussed above, HSSC devices have attractive features as low cost, long cyclic stability, excellent energy density, and power density, etc. The need for HSSC's in portable and wearable devices plays a crucial role due to its charge storage mechanism. The HSC is invented to enhance the energy density by sustaining high power density with long cycle life. HSSC devices are made up of one battery electrode (extrinsic PC), which provides energy density due to redox reaction, and another is the capacitive (EDLC) electrode, which gives high power 
density by surface charge storage mechanism. There is a requirement of enhancing the energy density with the stability of HSSC devices for market availability. Hence, we have summarized some current challenges and upcoming research directions for HSSC devices.

The energy and power density of the HSSC devices mainly depend on the potential window, active material, electrolyte, and conductivity (ionic and electronic). The energy density of HSSC's can be enhanced by combining two electrodes working in different potential windows in the same electrolyte. The electrolyte plays a critical role in enhancing potential window and hence electrochemical performance. In aqueous electrolyte, the potential window is restricted to $1.0 \mathrm{~V}$, while organic and ionic liquids electrolytes shift potential window beyond $1.0 \mathrm{~V}$. So, it is necessary to develop/prepare an organic and ionic liquid electrolyte that provides high ionic conductivity in solid state electrolyte suitable for both electrodes.

Another challenge direction is the fabrication of HSSC's in nano-/microstructure, having enhanced energy density, power density, and cycling stability with minimum self-discharge. Current challenges are dealing with the self-discharging of the device; and accomplishing the goal of storing maximum energy.

In summary, this review article focuses on key information about SC's, their types, and electrode materials for hybrid solid-state SC's. Also, the SC mechanisms are discussed in details. The merits/demerits of EDLC and PC's over the extrinsic PC are discussed. The recent progress in HSSC's suggests that it has a great future in flexible and wearable SC devices.

\section{Acknowledgment}

Author Ms. S. B. Dhavale would like to acknowledge the University Grant Commission (UGC) Government of India for providing financial assistance through the UGC-NET JRF fellowship. Author Ms. S. A. Beknalkar would like to acknowledge to DST-INSPIRE for providing financial assistance. Authors are thankful to DST-PURSE Phase-II (2018-2023) and UGC DSA -Phase II (2018-2023) Programme for providing research facilities at the Department of Physics, Shivaji University, Kolhapur, M.S., India.

\section{Support information}

Not applicable

\section{Conflict of Interest}

There are no conflicts to declare.

\section{References:}

[1] S. Zheng, Z. Li, Z. S. Wu, Y. Dong, F. Zhou, S. Wang, Q. Fu, C. Sun, L. Guo, X. Bao, ACS Nano, 2017, 11, 4009-4016, doi: 10.1021/acsnano.7b00553.

[2] Z. Yang, J. Zhang, M. C. Kintner-Meyer, X. Lu, D. Choi, J. P.
Lemmon, J. P.; Liu, J., Chem. Rev., 2011, 111, 3577-613, doi: $10.1021 / \mathrm{cr} 100290 \mathrm{v}$

[3] B. Naresh, T. Krishna, S. Rao, H. J. Kim, Mater. Lett., 2019, 248, 218-221, doi: 10.1016/j.matlet.2019.04.052.

[4] M. Winter, R. J. Brodd, Chem. Rev., 2004, 104, 4245-4270, doi: $10.1021 / \mathrm{cr} 020730 \mathrm{k}$.

[5]. J. M. Tarascon, M. Armand,. Nature, 2001, 414, 359-67, doi: $10.1038 / 35104644$.

[6] X. Shi, Z. Wu, J. Qin, S. Zheng, S. Wang, F. Zhou, C. Sun, X. Bao, Adv. Mater, 2017, 29, 1703034, doi: 10.1002/adma.201703034.

[7] M. Salanne, B. Rotenberg, K. Naoi, K. Kaneko, P. Taberna, C. P. Grey, B. Dunn, P. Simon, Nature Energy, 2016, 1, 16070, doi: 10.1038/nenergy.2016.70.

[8] J. Miller, A. Burke, Electrochem. Soc. Interface 2008, 17, 5357, doi: 10.1201/9781420069709.ch8

[9] P. Simon, Y. Gogotsi, Nature Mater., 2008, 7, 845-854, doi: $10.1038 /$ nmat2297.

[10] R. Rousseau, V. A. Glezakou, A. Selloni, Nature Rev. Mater., 2020, 5, 460-475, doi: 10.1038/s41578-020-0198-9.

[11] P. Hall, M. Mirzaeian, S. Fletcher, F. Sillars, A. Rennie, G. Shitta-Bey, G. Wilson, A. Cruden, R. Carter, Energy Environmental Sci., 2010, 3, 1238-1251, doi: 10.1039/C0EE00004C.

[12] J. Chmiola, G. Yushin, Y. Gogotsi, C. Portet, P. Simon, P. L. Taberna, Science, 2006, 313, 1760-3, doi: 10.1126/science.1132195.

[13] A. Ghosh, Y. H. Lee, ChemSusChem., 2012, 5, 480-99, doi: 10.1002/cssc. 201100645 .

[14] P. Simon, Y. Gogotsi, Accounts Chem. Res., 2013, 46, 1094-1103, doi: 10.1021/ar200306b.

[15] V. Augustyn, P. Simon, B. Dunn, Energy Environmental Sci., 2014, 7, 1597-1614, doi: 10.1039/C3EE44164D.

[16] A. M. Teli, S. A. Beknalkar, D. S. Patil, S. A. Pawar, D. P. Dubal, V. Y. Burute, T. D. Dongale, J. C. Shin, P.S. Patil, Appl. Surface Sci., 2020, 511, 145466, doi: 10.1016/j.apsusc.2020.145466.

[17] A. González, E. Goikolea, J. A. Barrena, R. Mysyk, J Renewable Sustainable Energy Rev., 2016, 58, 1189-1206, doi: 10.1016/j.rser.2015.12.249.

[18] L. L. Zhang, X. S. Zhao, Chem. Soc. Rev., 2009, 38, 2520 31, doi: 10.1039/B813846J.

[19] Z. S. Iro, C. Subramani, S.A. Dash, Int. J. Electrochem. Sci, 2016, 11, 10628-10643, doi: 10.20964/2016.12.50.

[20] G. Singh, K. S. Lakhi, S. Sil, S. V. Bhosale, I. Kim, K. Albahily, A. Vinu, Carbon, 2019, 148, 164-186, doi: 10.1016/j.carbon.2019.03.050.

[21] S.A. Jadhav, S. B. Dhavale, A. H. Patil, P. S. Patil, Mater. Design Processing Commun., 2019, 1, e83, doi: 
$10.1002 / \mathrm{mdp} 2.83$.

[22] Y. Dong, Z. S. Wu, W. Ren, H. M. Cheng, X. Bao, Sci. Bull., 2017, 62, 724-740, doi: 10.1016/j.scib.2017.04.010.

[23] S. Guo, S. Dong, Chem Soc Rev, 2011, 40, 2644-72, doi: 10.1039/C0CS00079E.

[24] M. Pumera, Energy Environ. Sci., 2011, 4, 668-674, https://doi.org/10.1039/C0EE00295J.

[25] Z. Chen, V. Augustyn, J. Wen, Y. Zhang, M. Shen, B. Dunn, Y. Lu, Adv. Mater., 2011, 23, 791-795, doi: 10.1002/adma.201003658.

[26] C. Yu, Y. Wang, H. Zheng, J. Zhang, W. Yang, X. Shu, Y. Qin, J. Cui, Y. Zhang, Y. Wu, J. Solid State Electrochem., 2017, 21, 1069-1078, doi: 10.1007/s10008-016-3441-y.

[27] W. Wei, X. Cui, W. Chen, D. G. Ivey, Chem.Soc. Rev., 2011, 40, 1697-721, doi: 10.1039/C0CS00127A.

[28] S. K. Shinde, H. M. Yadav, S. Ramesh, C. Bathula, N. Maile, G. S. Ghodake, H. Dhaygude, D. Y. Kim, J. Molecular Liquids 2020, 299, 112119, doi: 10.1016/j.molliq.2019.112119.

[29] J. V. Patil, S. S. Mali, J. S. Shaikh, T. S. Bhat, C. Hong, J. H. Kim, P. S. Patil, Applied Physics A , 2018, 124, 592, doi: 10.1007/s00339-018-1937-2.

[30] S.A. Pawar, D. S. Patil, J. C. Shin, ChemElectroChem, 2019, 6, 522-534, doi: 10.1002/celc.201801207.

[31] H. M. Yadav, G. S. Ghodake, D. Y. Kim, S. Ramesh, N. C. Maile, D. S. Lee, S. K. Shinde, Colloids Surfaces B: Biointerfaces, 2019, 184, 110500, doi: 10.1016/j.colsurfb.2019.110500.

[32] J. Qin, F. Zhou, H. Xiao, R. Ren, Z. S. Wu, Sci. China Mater, 2018, 61, 233-242, doi: 10.1007/s40843-017-9132-8.

[33] R. Ramya, R. Sivasubramanian, M. Sangaranarayanan, Electrochim. Acta, 2013, 101, 109-129, doi: 10.1016/j.electacta.2012.09.116.

[34] D. S. Patil, J. S. Shaikh, S. A. Pawar, R. S. Devan, Y. R. Ma, A. V. Moholkar, J. H. Kim, R. S. Kalubarme, C. J. Park, P. S. Patil, Phys. Chem. Chem. Phys., 2012, 14, 11886-11895, doi: $10.1039 / \mathrm{C} 2 \mathrm{CP} 41757 \mathrm{~J}$.

[35] M. Zheng, L. Li, P. Gu, Z. Lin, W. Du, H. Xue, H. Pang, Energy Technol., 2017, 5, 544-548, doi: 10.1002/ente.201600391. [36] S. K. Shinde, G. S. Ghodake, N. C. Maile, H. M. Yadav, A. D. Jagadale, M. B. Jalak, A. A. Kadam, S. Ramesh, C. Bathula, D. Y. Kim, Electrochimica Acta, 2020, 341, 135973, doi: 10.1016/j.electacta.2020.135973.

[37] X. Lu, M. Yu, G. Wang, Y. Tong, Y. Li, Energy Environmental Sci., 2014, 7, 2160-2181, doi: 10.1039/C4EE00960F.

[38] C. Meng, C. Liu, L. Chen, C. Hu, S. Fan, Nano Lett., 2010 , 10 , 4025-31, doi:10.1021/nl1019672.

[39] C. Zhong, Y. Deng, W. Hu, J. Qiao, L. Zhang, J. Zhang, Chem. Soc. Rev., 2015, 44, 7484-7539, doi: 10.1039/C5CS00303B
[40] A. Muzaffar, M. B. Ahamed, K. Deshmukh, J. Thirumalai, Renewable Sustainable Energy Rev., 2019, 101, 123-145, doi: 10.1016/j.rser.2018.10.026.

[41] F. Wang, X. Wu, X. Yuan, Z. Liu, Y. Zhang, L. Fu, Y. Zhu, Q. Zhou, Y. Wu, W. Huang, Chem Soc Rev, 2017, 46, 6816-6854, doi: 10.1039/C7CS00205J.

[42] J. S. Shaikh, N. S. Shaikh, R. Kharade, S. A Beknalkar, J. V. Patil, M. P. Suryawanshi, P. Kanjanaboos, C. K. Hong, J. H. Kim, P. S. Patil, J. Colloid Interface Sci., 2018, 527, 40-48, doi: 10.1016/j.jcis.2018.05.022.

[43] N. Choudhary, C. Li, J. Moore, N. Nagaiah, L. Zhai, L.; Jung, Y.; Thomas, J., Asymmetric supercapacitor electrodes and devices. Adv. Mater, 2017, 29, 1605336, doi: 10.1002/adma.201605336.

[44] T. Brousse, D. Bélanger, J. W. Long, J. Electrochem. Soc., 2015, 162, A5185-A5189, I: doi: 10.1149/2.0201505jes.

[45] Y. G. Wang, Z. D. Wang, Y. Y. Xia, Electrochim. Acta, 2005, 50, 5641-5646, doi: 10.1016/j.electacta.2005.03.042.

[46] I. Ryu, G. Kim, H. Yoon, S. J. Ahn, S. Yim, RSC Adv., 2016, 6, 102814-102820, doi: 10.1039/C6RA22841K.

[47] D. K. Kim,P. Muralidharan, H. W. Lee, R. Ruffo, R. Y. Yang, C. K. Chan, H. Peng, R. A. Huggins, Y. Cui, Y., Nano Lett., 2008, 8 , 3948-3952, doi: 10.1021/n18024328.

[48] M. D. Hossain, M. M. Islam, M. J. Hossain, S. Yasmin, S. R. Shingho, N. A. Ananna, C. M. Mustafa, J. Energy Storage, 2020, 27, 101108, doi: 10.1016/j.est.2019.101108.

[49] Y. Gogotsi, R. M. Penner, ACS Nano, 2018, 12, 2081-2083, doi: 10.1021/acsnano.8b01914.

[50] N. Choudhary, C. Li, J. Moore, N. Nagaiah, L. Zhai, Y. Jung, Adv. Mater.s, 2017, 29, 1605336, doi: 10.1002/adma.201605336. [51] Z. Li, K. Ma, H. Mi, C. Ji, Z. Li, F. Guo, S. He, C. Wang, M. Xu, P. Pang, ChemElectroChem., 2020, 7, 517-525, doi: 10.1002/celc. 201901800 .

[52] A. Afif, S. M. Rahman, A. T. Azad, J. Zaini, M. A.Islan, A. K. Azad, J. Energy Storage, 2019, 25, 100852, doi: 10.1016/j.est.2019.100852.

[53] J. Tao, N. Liu, W. Ma, L. Ding, L. Li, J. Su, Y. Gao, J Sci. Rep., 2013, 3, 2286, doi: 10.1038/srep02286.

[54] D. P. Dubal, N. R. Chodankar, D. H. Kim, P. Gomez-Romero, Chem. Soc. Rev, 2018, 47(6), 2065-2129, doi: 10.1039/C7CS00505A.

[55] P. Yang, W. Mai, Nano Energy, 2014, 8, 274-290, doi: 10.1016/j.nanoen.2014.05.022.

[56] F. Zhang, T. Zhang, X. Yang, L. Zhang, K. Leng, Y. Huang, Y. Chen, Energy Environmental Sci., 2013, 6, 1623-1632, doi: 10.1039/C3EE40509E.

[57] Y. Wang, Y. Song, Y. Xia, Chem. Soc. Rev., 2016, 45, 59255950, doi: 10.1039/C5CS00580A.

[58] P. Simon, Y. Gogotsi, J Philosophical Trans. Royal Soc. A: 
Mathematical, Phys. Eng. Sci., 2010, 368, 3457-3467, doi: 10.1098/rsta.2010.0109.

[59] L. Piñeiro-Prado, D. Salinas-Torres, R. Ruiz-Rosas, E. Morallon, D. Cazorla-Amorós, Frontiers Mater. , 2016, 3, 16, doi: 10.3389/fmats.2016.00016.

[60] L.F. Aval, M. Ghoranneviss, G. B. Pour, Heliyon , 2018, 4 , e00862, doi: 10.1016/j.heliyon.2018.e00862.

[61] U. Fischer, R. Saliger, V. Bock, R. Petricevic, J. Fricke, J. Porous Mater, $1997, \quad 4, \quad 281-285$, doi: 10.1023/A:1009629423578.

[62] Q. Ke, J. Wang, J. Materiomics, 2016, 2(1), 37-54, doi: 10.1016/j.jmat.2016.01.001.

[63] P. C. Gao, W. Y. Tsai, B. Daffos, P. L. Taberna, C. Pérez, Y. Gogotsi, P. Simon, F. Favier, Nano Energy , 2015, 12, 197-206, doi: 10.1016/j.nanoen.2014.12.017.

[64] A. S. Levitt, M. Alhabeb, C. B. Hatter, A. Sarycheva, G. Dion, Y. Gogotsi, J. Mater. Chem. A, 2019, 7(1), 269-277, doi: 10.1039/C8TA09810G.

[65] R. A. Huggins, Energy Storage. Springer: 2010; Vol. 406.

[66] Y. Jiang, J. Liu, Energy Environmental Mater., 2019, 2 (1), 30-37, doi: 10.1002/eem2.12028.

[67] B. E. Conway, Electrochemical supercapacitors: scientific fundamentals and technological applications. Springer Science \& Business Media: 2013.

[68] B. E. Conway, V. Birss, J. Wojtowicz, J. Power Sources, 1997, 66, 1-14, doi: 10.1016/S0378-7753(96)02474-3.

[69] T. Brousse, M. Toupin, R. Dugas, L. Athouel, J. Electrochem. Soc., 2006, 153, A2171, doi: 10.1149/1.2352197.

[70] E. Watanabe, H. Ushiyama, K. Yamashita, Y. Morikawa, D. Asakura, M. Okubo, A. Yamada, J. Phys. Chem. C, 2017, 121, 18975-18981, doi: 10.1021/acs.jpcc.7b02500.

[71] P. Iamprasertkun, A. Krittayavathananon, A. Seubsai, N. Chanlek, P. Kidkhunthod, W. Sangthong, S. Maensiri, R. Yimnirun, S. Nilmoung, P. Pannopard, Sci. Rep., 2016, 6 , 1-12, doi: $10.1038 /$ srep37560.

[72] T. Brezesinski, J. Wang, S. H. Tolbert, B. Dunn, Nature Mater., 2010, 9(2), 146-151, doi: 10.1038/nmat2612.

[73] V. Augustyn, J. Come, M. A. Lowe, J. W. Kim, P. L. Taberna, S. H. Tolbert, H. D. Abruña, P. Simon, B. Dunn, Nature Mater, 2013, 12, 518-522, doi: 10.1038/nmat3601.

[74] L. Kong, C. Zhang, J. Wang, W. Qiao, L. Ling, D. Long, J ACS Nano, 2015, 9, 11200-11208, doi:10.1021/acsnano.5b04737.

[75] C. Chen, Y. Wen, X. Hu, X. Ji, M. Yan, L. Mai, P. Hu, B. Shan, Y. Huang, Nature Commun., 2015, 6, 1-8, doi: 10.1038/ncomms7929.

[76] C. Choi, D. S. Ashby, D. M. Butts, R. H. DeBlock, Q. Wei, J. Lau, B. Dunn, Nature Rev. Mater., 2019, 1, 5, dio: 10.1038/s41578-019-0142-z.

[77] M. Okubo, E. Hosono, J. Kim, M. Enomoto, N. Kojima, T.
Kudo, H. Zhou, I. Honma, J. Am. Chem. Soc., 2007, 129, 74447452, doi: 10.1021/ja0681927.

[78] H. Kim, J. Cook, H. Lin, J. Ko, S. Tolbert, V. Ozolins, B. Dunn, Nature Mater. , 2017, 16, 454-460, doi: 10.1038/nmat4810. [79] J. Mefford, W. Hardin, S. Dai, K. Johnston, K. Stevenson, Nature Mater., 2014, 13, 726-732, doi: 10.1038/nmat4000.

[80] N. R. Chodankar, H. D. Pham, A. Nanjundan, J. F. Fernando, K. Jayaramulu, D. Golberg, Y. Han, D. P. Dubal, Small, 2020, 16, 2002806, doi: 10.1002/smll.202002806.

[81] A. Eftekhari, Sustainable Energy Fuels, 2017, 1, 2053-2060, doi: 10.1039/C7SE00350A.

[82] J. Wang, J. Polle. J. Lim, B. Dunn, J. Phys. Chem. C, 2007, 111, 14925-14931, doi: 10.1021/jp074464w.

[83] A. J. Bard, L. R. Faulkner, Electrochemical Methods: Fundamentals and applications. Wiley: 2001; Vol. 2, p 864.

[84] W. Yan, J. Y. Kim, W. Xing, K. C. Donavan, T. Ayvazian, R. M. Penner, Chem. Mater., 2012, 24, 2382-2390, doi: $10.1021 / \mathrm{cm} 3011474$.

[85] T. S. Mathis, N. Kurra, X. Wang, D. Pinto, P. Simon, Y. Gogotsi, Adv. Energy Mater., 2019, 9, 1902007, doi: 10.1002/aenm.201902007.

[86] Y. Jiao, W. Hong, P. Li, L. Wang, G. Chen, Appl. Cat. B: Environmental, 2019, 244, 732-739, doi: 10.1016/j.apcatb.2018.11.035.

[87] Y. Liu, X. Wang, X. Jiang, X. Li, L. Yu, Nanoscale, 2018, 10, 22848-22860, doi: 10.1039/c8nr06966b.

[88] X. He, Y. Zhao, R. Chen, H. Zhang, J. Liu, Q. Liu, D. Song, R. Li, J. Wang, ACS Sustainable Chem. Eng., 2018, 6, 1494514954, doi: 10.1021/acssuschemeng.8b03440.

[89] F. Chen, H. Wang, S. Ji, V. Linkov, R. Wang, Mater. Today Energy, 2019, 11, 211-217, doi: 10.1016/j.mtener.2018.12.002.

[90] Y. Wang, X. Lin, T. Liu, H. Chen, S. Chen, Z. Jiang, J. Liu, J. Huang, M. Liu, Adv. Funct. Mater., 2018, 28, 1806207, doi: 10.1002/adfm.201806207.

[91] X. Wang, H. Li, H. Li, S. Lin, J. Bai, J. Dai, C. Liang, X. Zhu, Y. Sun, S. Dou, J. Mater. Chem. A, 2019, 7(5), 2291-2300, doi: 10.1039/C8TA11249E.

[92] Y. Liu, N. Liu, L. Yu, X. Jiang, X. Yan, Chem. Eng. J., 2019, 362, 600-608, doi: 10.1016/j.cej.2019.01.058.

[93] D. Kong, C. Cheng, Y. Wang, J. L. Wong, Y. Yang, H. Y. Yang, J. Mater. Chem. A, 2015, 3, 16150-16161, doi: 10.1039/C5TA03469H.

[94] M. Wei, C. Wang, Y. Yao, S. Yu, W. H. Liao, J. Ren, R. Sun, C. P Wong, Chem. Eng. J., 2019, 355, 891-900, doi: 10.1016/j.cej.2018.08.223.

[95] N. R. Chodankar, D. P. Dubal, S. J. Patil, S. S. Raju, S. V. Karekar, Y. S. Huh, Y. K. Han, Electrochim. Acta, 2019, 319, 435 443, doi: 10.1016/j.electacta.2019.06.166.

[96] K. R. Shrestha, S. Kandula, G. Rajeshkhanna, M. Srivastava, 
N. H. Kim, J. Lee, J. Mater. Chem. A , 2018, 6, 24509-24522.

[97] G. Li, H. Cai, X. Li, J. Zhang, D. Zhang, Y. Yang, J. Xiong, ACS Appl. Mmater. Interfaces, 2019, 11, 37675-37684, doi: 10.1021/acsami.9b11994.

[98] H. Xia, G. Li, H. Cai, X. Li, P. Sun, P. Wang, J. Huang, L. Wang, D. Zhang, Y. Yang, Dalton Trans., 2019, 48 (32), 1216812176, doi: 10.1039/c9dt02227a.

[99] G. Qu, P. Sun, G. Xiang, J. Yin, Q. Wei, C. Wang, X. Xu, Appl. Mater. Today, 2020, 20, 100713, doi: 10.1016/j.apmt.2020.100713.

[100] S. He, Z. Li, H. Mi, C. Ji, F. Guo, X. Zhang, Z. Li, Q. Du, J. Qiu, J. Power Sources, 2020, 467, 228324, doi: 10.1016/j.jpowsour.2020.

[101] X. Yin, H. Li, Y. Fu, R. Yuan, J. Lu,. Chem. Eng. J., 2020, 392, 124820, doi: 10.1016/j.cej.2020.124820.

[102] H. Liu, H. Guo, W. Yao, L. Zhang, M. Wang, T. Fan, W. Yang, W. Yang, Colloids Surf. A: Physicochem. Eng. Aspects, 2020, 601, 125011, doi: 10.1016/j.colsurfa.2020.125011.

[103] G. Zhao, Y. Tang, G. Wan, X. Xu, X. Zhou, M. Zhou, C. Hao, S. Deng, G. Wang, J. Colloid Interface Sci, 2020, 572, 151 159, doi: 10.1016/j.jcis.2020.03.084 .

[104] Z. Li, S. He, C. Ji, H. Mi, C. Lei, Z. Li, H. Pang, Z. Fan, C. Yu, J. Qiu, J, Adv. Mater. Interfaces, 2019, 6, 1900959, doi: 10.1016/j.jpowsour.2019.04.062.

[105] P. Sun, N. Li, C. Wang, J. Yin, G. Zhao,P. Hou, X. Xu, J. Power Sources, 2019, 427, 56-61, 10.1016/j.jpowsour.2019.04.062.

\section{Author information}

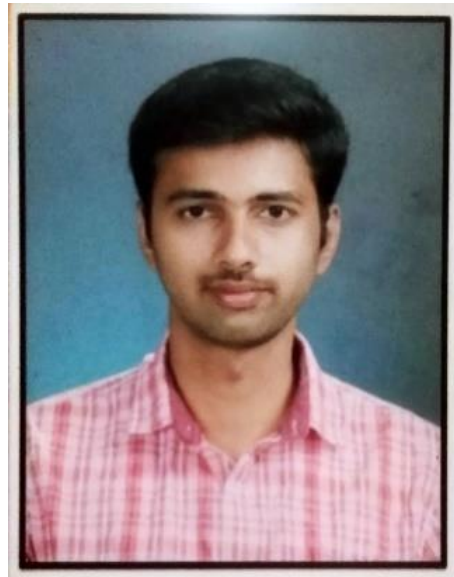

Mr. Satyajeet S. Patil, is currently working as a research student under the supervision of Prof. Pramod S. Patil, Thin Film Materials Laboratory, Department of Physics, Shivaji University, Kolhapur since 2019. $\mathrm{Mr}$. Satyajeet received his $M$. Sc. Degree (Solid State Physics) from Shivaji University Kolhapur in 2019. He is recipient of prestigious "The President of India Medal for General Proficiency", Shivaji University, Kolhapur in 2018. His main research interest is synthesis of nanostructured metal oxides and its composites for clean energy conversion and storage applications. He has published more than 4 research articles in reputed journals. (ORCID: 0000-0002-4576-6136).

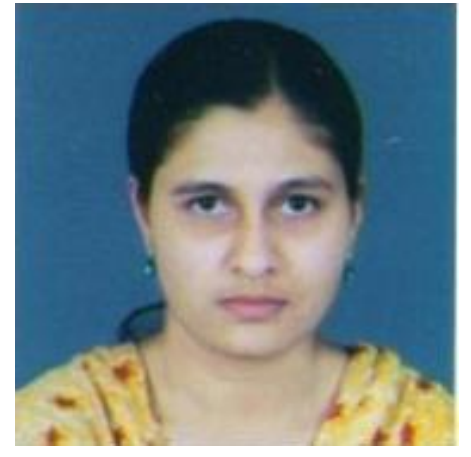

Dr. Tejasvinee Shrikrishna Bhat is currently working as Assistant Professor at School of Nanoscience and Technology, Shivaji University, Kolhapur. She completed his Ph.D. degree (2017) under the guidance of Prof. P. S. Patil at Department of Physics, Shivaji University Kolhapur. His research areas are solar cells, supercapacitor, electrochromism, and photocatalysis etc. He has published near about 24 research articles in well reputed international journals.

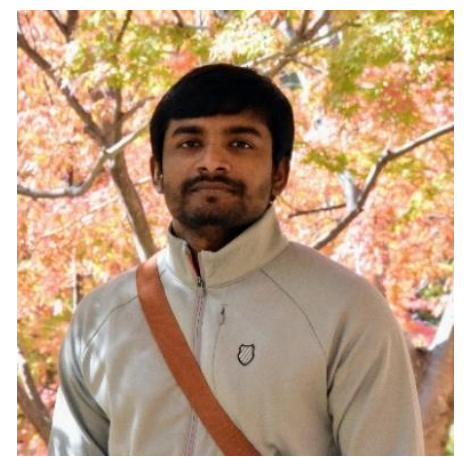

Dr. Aviraj Mahadev Teli is currently working as Post Doctorate fellow under the guidance of Prof. J. C. Shin at Department of Physics, Yeungnam University, South Korea. He completed his Ph.D. degree (2019) under the guidance of Prof. P. S. Patil at Department of Physics, Shivaji University Kolhapur. His research areas are electrochemical energy storage devices, supercapacitor, electrochromism, and memorister etc. He has published near about 20 research articles in well reputed international journals.

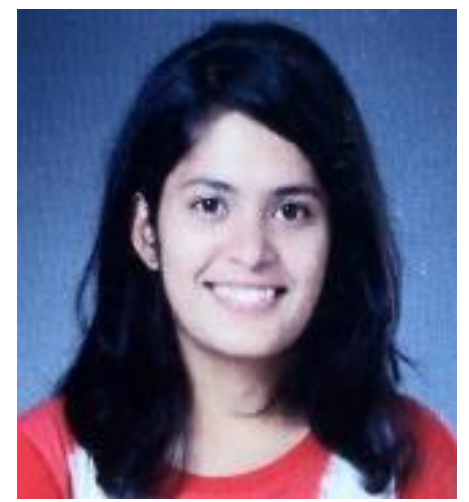

Miss. Sonali A. Beknalkar is currently working as research scholar under the guidance of Prof. Pramod S. Patil, Head, Department of Physics, Shivaji University Kolhapur. She is a recipient of DSTINSPIRE fellowship since 2018. She completed her master degree (in 2017) in Solid state Physics at Shivaji University, Kolhapur. Her main research interest is to synthesize nanostructured metal oxides composites for energy storage applications. She has published more than 7 research articles in several international journals of well repute. 


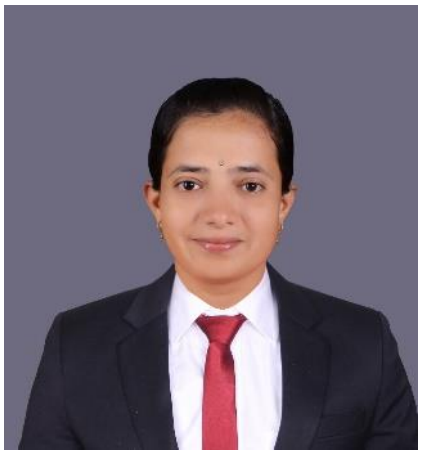

Miss. Sarika B. Dhavale, UGC

NET junior research fellow, currently pursuing her Ph.D.degree under the guidance of Prof. Pramod S. Patil at the Shivaji University, Kolhapur, India. She has completed her graduation from the Shivaji University; Kolhapur in 2015.She obtained her post graduation (M.Sc.) degree from the same university. In the year 2017, she has qualified UGC NET-JRF in Physics with AIR 172. She is working in the field of energy storage application. Her research work is focused on the development of low cost, sustainable energy storage devices such as batteries and supercapacitors by using biomass waste derived carbon materials.

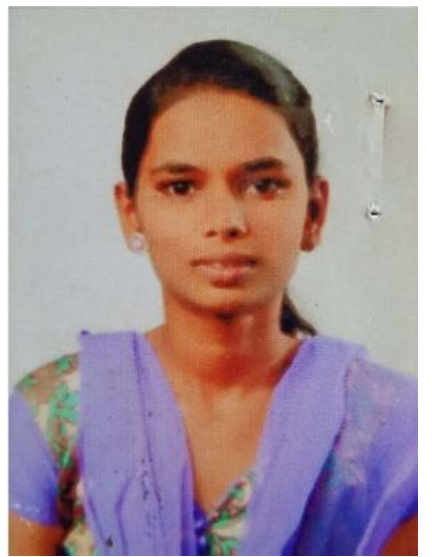

Miss. Minaj M. Faras, is currently working as a research student under the guidance of Dr. Appasaheb P. Torane, Solid state material laboratory, department of physics, Yashavantarao chawan institute of science, satara. Miss. Minaj received her $B$.Sc. degree from Shivaji University Kolhapur in 2017, M.Sc. degree from Shivaji University Kolhapur in 2019. For Ph.D degree her research title is "Synthesis and characterization of Zinc Cobaltite- based electrode material for high performance energy storage devices". Her research interest is synthesis of nanomaterial for supercapacitor application.

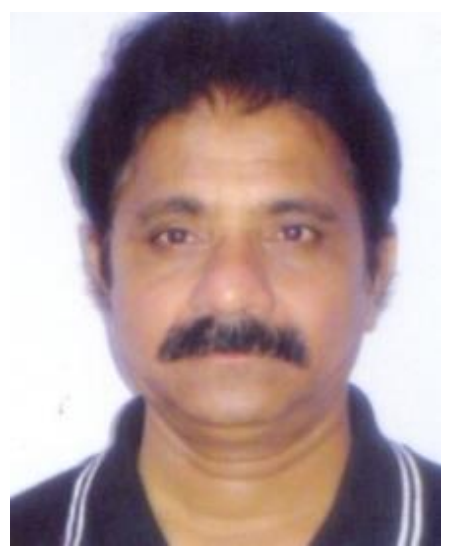

Prof. (Dr.) M. M. Karanjkar is currently working as a Head and Professor in the Department of Physics, Vivekanad College,Kolhapur. Prof. Karanjkar received his Ph. D. degree from Shivaji University Kolhapur, India in 1995. He has been continuously engaged in the research filed more than last 30 years. His research interest is in Magnetism, Solar cells, Gas sensors, Electrochromism and Supercapacitors.

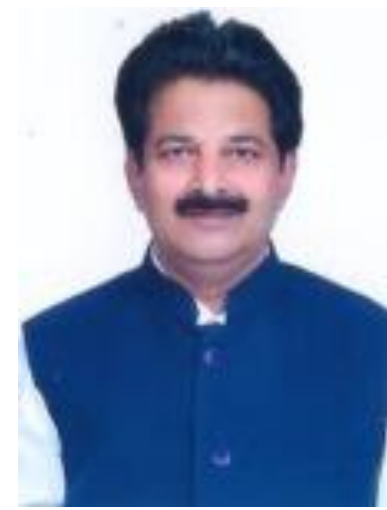

Prof. (Dr.) Pramod S. Patil is currently working as a Head and Professor in the Department of Physics and Founder Coordinator of School of Nanoscience and Technology, Shivaji University, Kolhapur. Also, he is former Coordinator of Department of Technology and Energy Technology, Shivaji University, Kolhapur. He is Dean of Science \& Technology and DAAD and brain pool Fellow. He is recipient of best teacher award in 2014. Prof. Patil received his Ph. D. degree from Shivaji University Kolhapur, India in 1990. He has been continuously engaged in the research filed more than last 32 years. His research interest is in Solar cells, Gas sensors, Nanotextiles, Electrochromism and Supercapacitors. He has published more than 450 research articles for well reputed journals. He received more than 20,000 research citations for his research articles with h-index 72

Publisher's Note: Engineered Science Publisher remains neutral with regard to jurisdictional claims in published maps and institutional affiliations. 